Stirling Management School

Constructing Genuine Savings Indicators for Ireland, 1995-2005

Susana Ferreira

Mirko Moro (corresponding author)

Stirling Economics Discussion Paper 2010-10

September 2010

Online at http://www.economics.stir.ac.uk 


\title{
CONSTRUCTING GENUINE SAVINGS INDICATORS FOR IRELAND, 1995-2005*
}

\author{
Susana Ferreira \\ Department of Agricultural and Applied Economics, 313 Conner Hall, University of Georgia, \\ Athens, Georgia 30602-7509, USA. Tel: +17065420086. Email:sferreir@uga.edu \\ Mirko Moro (corresponding author) \\ Division of Economics, University of Stirling, Stirling, FK9 4LA, UK. \\ Tel: +44(0)1786466409 Email: mirko.moro@stir.ac.uk. \\ Economic and Social Research Institute, Whitaker Square, Sir John Rogerson's Quay, Dublin 2
}

\begin{abstract}
In this paper we compute the genuine savings indicators for the Republic of Ireland over the period 1995-2005. We expand and improve existing World Bank's estimates by: a) using data collected from official Irish sources; b) employing the net present value method to assess resource depreciation; c) including external costs from $\mathrm{SO}_{2}$ and $\mathrm{NOx}$ emissions; and d) estimating human capital accumulation using the returns to education. We also perform a sensitivity analysis to check the robustness of our estimates to different assumptions and parameters. Our estimates are consistently smaller than the World Bank's and negative in the first years of the period considered.
\end{abstract}

\footnotetext{
* We would like to thank Ben Dhonau and Wayne Cox for their patience answering our questions on extraction activities in Ireland and their expertise and effort in updating all the figures we present; Ken Cleary for historical data on production of minerals, Michael Hanrahan for data on natural gas; J. Owen Lewis and Charles Shier for information on peat. We also thank Terrence Mc Fadden, Marcus Collier, J. Peter Clinch for insightful discussions, participants at the EPA STRIVE seminars in 2006 and 2007 and three anonymous reviewers for useful comments. Funding from Ireland's EPA STRIVE programme is gratefully acknowledged.
} 


\section{Introduction}

Over the 1990s the Irish economy grew at a record rate for a developed country. Between 1990 and 2000, Gross Domestic Product doubled with the real annual growth rate at a high of 11 percent in 1999. Despite an impressive performance in terms of conventional macroeconomic indicators such as Gross National Product (GNP) or Gross Domestic Product (GDP), there has been much concern regarding the implications of the pace of economic growth for environmental quality and sustainability more generally (Clinch, 2001). It is well understood that GNP and GDP offer an incomplete answer to the sustainability question as they omit non-marketed public goods such as environmental quality (Nordhaus, 2000), and include consumption of capital assets such as natural resources as production of income (Dasgupta, 2001; Repetto et al., 1989).

Economic theory suggests that an operationalisable indicator of sustainable development should be based on inclusive or comprehensive wealth (see e.g., Dasgupta and Mäler, 2000; Hamilton and Clemens, 1999; Arrow et al., 2003). The intuition behind this is straightforward. The complete array of assets -which includes human and natural capitalcan be conceived as the productive base of an economy and therefore as a key determinant of future national well-being. The value of changes in these assets today must have future, long-run, welfare consequences. Positive changes can be regarded as good news from a sustainability point of view, whilst negative changes are a signal of a potential decline in social well-being in the future. Alternatively, comprehensive net national product (NNP), calculated as GNP minus depreciation of all forms of capital, can be interpreted as the maximum level of consumption that maintains the capital stock intact. ${ }^{1}$

The first empirical estimates of inclusive net savings were computed by Pearce and Atkinson (1993). ${ }^{2}$ Today, the World Bank publishes estimates of comprehensive savings for over 100 countries, including the Republic of Ireland, after the empirical investigation by Hamilton and Clemens (1999). ${ }^{3}$ The Bank constructs these estimates by making a series of adjustments to gross national savings. The principal adjustments are to subtract a

\footnotetext{
${ }^{1}$ See Dasgupta (2009) and Asheim (2003) for detailed reviews of the green accounting literature.

2 This indicator has been termed 'genuine savings' (Hamilton, 1994), 'net investments' (Dasgupta and Mäler, 2000) or 'adjusted net savings.' In the remaining of the paper we will use these terms interchangeably. The theoretical precursors of the genuine savings indicator can be traced back to the work of Weitzman (1976), Hartwick (1977) and Solow (1986).

${ }^{3}$ The most recent estimates can be found online at http://go.worldbank.org/8CWDARYMB0.
} 
depreciation allowance for produced capital stocks and depletion allowances for fossil fuels, ${ }^{4}$ minerals, ${ }^{5}$ and timber, and to add investment in human capital. The methods are similar across countries and rely on standard international data sources. ${ }^{6}$

Ferreira and Vincent (2005) point out several shortcomings of the Bank's estimates. The most general is that they are not truly comprehensive: although the Bank makes adjustments for the depletion of an impressively wide range of natural resources, the adjustments to account for the degradation of others such as water and the atmosphere are much more limited. A second shortcoming is measurement error in the estimates that the Bank includes.

In this paper, we compute the genuine savings indicators for Ireland over the period 19952005 and, in doing so, aim to improve the existing World Bank indicators in four ways. First, we use data on production and prices of physical, natural and human capital from various official Irish sources and literature, limiting the use of regional and international averages and estimates. For example, the data on mineral production used by the World Bank is from the USGS Mineral Yearbook, which differs from the official information from the Irish Exploration and Mining Division. Even the data on gross national savings from the National Accounts are substantially different (CSO, 2008). Second, we use the net present value method to assess the depreciation of market natural resources. This method is recommended by national and international statistical agencies over the 'net price' method employed by the World Bank (see UN, 1993; Common and Sanyal, 1998). Third, we expand the valuation of environmental degradation by including estimates of external costs from sulphur dioxide $\left(\mathrm{SO}_{2}\right)$ and nitrogen oxides (NOx) emissions in addition to $\mathrm{PM}_{10}$ and $\mathrm{CO}_{2}$ emissions. Although, compared to $\mathrm{CO}_{2}$, the residence time of $\mathrm{PM}_{10}, \mathrm{SO}_{2}$ and $\mathrm{NOx}$ in the atmosphere is relatively short and thus they are not strictly stock pollutants, they inflict damages on other forms of capital, for example on human capital in terms of excess mortality and chronic morbidity. Fourth, we value human capital accumulation using the returns to education, i.e. the market premium of higher education as reflected in higher wages. Finally, we analyzed the sensitivity of our estimates to different parameters.

\footnotetext{
${ }^{4}$ Oil, natural gas, and coal.

${ }^{5}$ Bauxite, copper, gold, iron, lead, nickel, phosphate, silver, tin and zinc.

${ }^{6}$ Hamilton and Clemens (1999) and Bolt et al. (2002) describe the methods used by the Bank to make these adjustments. For more recent work see World Bank (2006).
} 
Our estimates of genuine savings for Ireland over the period 1995-2005 are consistently smaller than those reported by the World Bank. In fact, according to our estimates, Ireland has experienced negative genuine savings in two of the years considered, 1995 and 1996, and negative or close to zero savings in 1997 in all but one of our specifications. In recent years, however, genuine savings are positive and increasing. This finding is in sharp contrast with existing estimates by the World Bank and other studies that consistently find positive genuine savings for developed countries. ${ }^{7}$ Our results confirm the importance of expanding on the World Bank's adjustments and show that when including externalities derived from the use of public goods such as air, which typically are not taken into consideration when building macroeconomic indicators of sustainability, developed countries may be shown as having sustainability problems.

The remaining of the paper is structured as follows: in Section 2 we present the theoretical framework and the methodology. In Section 3 we introduce the data used to compute the Irish genuine savings. In Section 4 we present the results, compare our estimates of genuine savings with those of the World Bank, and analyze their robustness to changes in key parameters and assumptions. Section 5 concludes.

\section{Theory and Methodology}

\subsection{Theoretical Framework}

Our empirical measure of genuine savings is based on the theoretical work of Arrow, Dasgupta and Mäler on intertemporal welfare for imperfect economies (Dasgupta and Mäler, 2000; Arrow et al., 2003; 2004). The wealth of an economy, $W$, at time $t$ can be expressed as the sum of a comprehensive set of assets: $K$ (human-made capital), $H$ (human capital) and $S$ (natural capital), evaluated at their shadow prices: ${ }^{8}$

$$
W_{t}=\kappa_{t} K_{t}+\mu_{t} H_{t}+\lambda_{t} S_{t}
$$

\footnotetext{
7 To our knowledge, only Hanley et al. (1999) has shown negative genuine savings for a rich economy, Scotland, over the 1980s.

${ }^{8}$ In principle, all the assets that contribute to producing welfare should be considered, including social and institutional capital. In practice, given the data and conceptual problems associated with the measurement of these two intangible assets, we focus on physical, natural and human capital.
} 
It can be shown (see, for example, Dasgupta 2009, proposition 1) that for constant population and exogenous movements in total factor productivity and import and export prices, the change in $W$, or genuine savings $(G S)$, equates the change in social well-being, when social well-being is expressed using a Ramsey-Koopmans formulation, $V_{t}=\int_{0}^{\infty} U\left(C_{\tau}\right) \mathrm{e}^{-\delta(\tau-t)} \mathrm{d} \tau$ :

$$
\mathrm{d} V_{t} / \mathrm{d} t=G S_{t}=\kappa_{t} \mathrm{~d} K_{t} / \mathrm{d} t+\mu_{t} \mathrm{~d} H_{t} / \mathrm{d} t+\lambda_{t} \mathrm{~d} S_{t} / \mathrm{d} t
$$

From (2) it follows that the value of changes in comprehensive wealth has the same sign as the corresponding change in intergenerational well being. If $G S_{t} \leq 0$ the economy is deemed as unsustainable. Notice, however, that a welfare improvement at a given moment in time, $\mathrm{d} V_{t} / \mathrm{d}_{t}=G S_{t}>0$, is weaker than long term sustainability; i.e. in an imperfect economy, the genuine savings indicator - even if perfectly estimated- is not a perfect sustainability indicator. A country seeking short-term growth at the expense of long-term viability may with a positive utility discount rate have both growth in comprehensive NNP and positive value of changes in a comprehensive vector of stocks to begin with, even though long term sustainability is undermined. To judge whether an economy is sustainable the entire equilibrium path must be examined. ${ }^{9}$ These issues must be kept in mind when interpreting our estimates.

\subsection{Methodology}

We follow standard practice (see e.g. Hamilton and Clemens 1999, World Bank 2006) and calculate genuine savings by subtracting from gross national savings (GNS) estimates of fixed capital depreciation $\left(D_{K}\right)$, depletion of natural resources $\left(D_{S}\right)$, environmental degradation $\left(D_{E}\right)$, and adding human capital accumulation $\left(A_{H}\right)$.

$$
\hat{G} S_{t}=G N S_{t}-D_{K t}-D_{S t}-D_{E t}+A_{H t} .
$$

\footnotetext{
${ }^{9}$ For an illustration see Asheim (1994, Section IV). Pezzey and Toman (2002) refer to GS as a "one-sided" sustainability measure. They also discuss the practical implications and the limitations of using market prices to construct sustainability tests. They argue that not even 'efficient prices' (those that induce an optimal allocation of resources) are suitable and that 'sustainability prices' (those that induce a sustainable path of utility) are required (Pezzey and Toman 2002, 2005).
} 
Gross national savings is reported in the Irish National Accounts (CSO, 2008) and is equal to gross national income minus national total consumption. The other adjustments in the right hand side of equation (3) are described below.

\subsubsection{Depreciation of physical capital}

By using gross national income (as opposed to gross domestic income) as the starting point of our calculations, we are able to account for ownership of the reproducible capital to reflect that some of the stock of physical capital in Ireland is owned by foreign investors, and vice versa. The interest payments derived from the foreign financial assets or obligations will affect future levels of consumption of Irish residents. The adjustment of the savings estimates to account for ownership is particularly important in the light of the acceleration in cross border asset trade observed in the last decades. ${ }^{10}$

\subsubsection{Depreciation of natural capital}

The World Bank equates the depletion of fossil fuels and minerals to current resource rent (quantity extracted times the difference between price and average total cost of extraction), using the 'net price' method (see e.g., Repetto et al., 1989). This ignores the appreciation of remaining reserves that occurs as time passes and future rents come closer to the present $(\mathrm{El}$ Serafy, 1989; Hartwick and Hagemann, 1993). Empirical work by Neumayer (2000) suggests that this can exaggerate the loss in value of reserves enormously. Moreover, the net price method captures the true value of asset depreciation only under strong assumptions of optimal management, endogenous prices and costs, and if average costs are good proxies of marginal costs (Perrings and Vincent, 2003).

In this paper we use an alternative method proposed by El Serafy (1989). This method, known as the 'simple present value method,' imposes no optimization on the extraction path of the resource, but assumes constant total rents and requires information on the lifetime of the resource. Because it implicitly takes into account the appreciation of reserves closer to extraction, this method yields lower values for depreciation (see Atkinson and Hamilton, 2007 Table 2, p. 49). ${ }^{11}$ For a more thorough comparison of both methods and derivation of

\footnotetext{
${ }^{10}$ For example, an indicator of financial integration used by Lane and Milesi-Ferretti (2007), the sum of external assets and liabilities over GDP, increased by a factor of 7 in developed countries, from $45 \%$ in 1970 to over $300 \%$ in 2004, with a clear acceleration in the mid 1990s. The same indicator of financial integration in Ireland increased by a factor of 17 , from $115 \%$ in 1970 to over $1,900 \%$ in 2004.

${ }^{11}$ Allowing for capital gains in natural resources is a relaxation of the theoretical framework presented in Section 2.1; shadow prices in equation (2) are constant. In practice, capital gains influence future consumption
} 
the expression for $D_{S t}$ see Appendix A. Regarding the choice of discount rate for the computation of $D_{S t}$, estimates for industrial countries range from $2 \%$ to $4 \%$ (Zerbe and

Dively, 1994; Pearce and Ulph, 1998). Since Ireland has experienced an economic boom with very high levels of consumption in recent years, perhaps suggesting impatience, we would favour the use of higher discount rates. However, following best practice in the literature, we used a 2, 4, and 6\% discount rate (Pezzey et al., 2006).

A caveat of both, the net price and simple present value methods is that they are able to capture only the use value of the resource. For many market resources, such as fossil fuels and metals and minerals, this may be appropriate, but for other resources, such as forests, non-use values (e.g. the intrinsic value that people may attach to them, or the option value of extending society's set of future options) may be important.

\subsubsection{Environmental Degradation}

A comprehensive measure of savings needs to account for the changes in all the stocks of assets, including those with negative shadow prices. The stock of green-house gases in the atmosphere associated with $\mathrm{CO}_{2}$ emissions, for example, falls into this category.

However, many pollutants are not stock but flow pollutants. How should we (if at all) account for their damages? First, the effects of pollution on output (e.g. damaged crops) are already reflected implicitly in the standard national accounts. Similarly, damages to produced assets (e.g. the damage to building materials caused by acid rain) should, in principle, be included in depreciation figures so there is no need to adjust savings measures in this regard. In practice, however, most statistical systems, including the Irish System of National Accounts, are not detailed enough to pick this up (Hamilton and Clemens 1999). Second, pollution may affect the productive capacity of other stocks such as human resources (excess mortality and chronic morbidity) or ecosystems (e.g. decreasing soil fertility). Hamilton (1996) and Atkinson and Hamilton (2007) argue that, in this case, the loss in asset value should be deducted from savings. In this vein, the World Bank adjusts genuine savings for damages from $\mathrm{PM}_{10}$ (particulate matter less than 10 microns in diameter) emissions. In addition to $\mathrm{PM}_{10}$, in this paper we consider the damages to assets from $\mathrm{SO}_{2}$ and $\mathrm{NOx}$, two of the most important air pollutants in Ireland (EPA Ireland, 2003).

possibilities, and thus, are relevant for our empirical estimates. Their impact, however, is likely to be small given Ireland's relatively small resource base. 
The adjustment for environmental degradation consists in deducting the change in the environmental component, $E$ (i.e., air or water net emissions), valued at society's marginal willingness to pay (WTP) to reduce emissions (Hamilton, 1996; Dasgupta, 2001; Atkinson and Hamilton, 2007). This WTP should reflect the present value of future impacts arising from current emissions.

$$
D_{E t}=W T P_{t}^{*}\left(\Delta E_{t} / \Delta t\right)
$$

The WTP could be based on marginal damage cost or marginal abatement cost. In general, the two approaches will differ in imperfect economies. Hamilton and Atkinson (1996) propose using damage costs as many real-world economies are more likely to be 'overpolluting' relative to the optimum.

What about 'pure' flow pollutants? These pollutants (e.g. noise, odour) are neither a stock nor affect other stocks. They cause damage, and thus, reduce the welfare of the population affected, but the damage (largely) ceases with exposure to the pollutant. Adjustment for their damages do not appear explicitly in GS but are included in green NNP (Pezzey et al. 2006).

Another important practical issue when valuing emissions damages (of a stock pollutant or a flow pollutant that damages a stock) has to do with transboundarity and global impacts. This is clear in the case of $\mathrm{SO}_{2}$ and $\mathrm{CO}_{2}$ emissions. Should we account for all the damages caused by Irish emissions in both Ireland and other countries or should we account for the damages to Ireland from worldwide emissions? In its adjustment for $\mathrm{CO}_{2}$ emissions, the World Bank charges global damages (a global marginal social cost of \$20 per metric ton of carbon, taken from Fankhauser (1994 and 1995)) to emitting countries on the assumption that the property right to a clean environment lies with the pollutee. ${ }^{12}$ This is the approach postulated in Hamilton and Clemens (1999, p. 342), and used in Arrow et. al (2004, Table 1, p.163). However, absent a mechanism to compensate the recipients of damages arising from transboundary pollution, we also considered the alternative approach that assumes that the property rights to use the atmosphere as a sink lie with the polluter. Under this second approach, used by Arrow et al. (2007), we consider the damages to Ireland arising from global emissions. In the case of $\mathrm{SO}_{2}$, the estimates available to us reflect damages from Irish

12 Note that most studies on the economics of climate change do not specify the year for which the estimate is valid. In this paper we followed Tol's suggestions of working "with the assumption that the social cost of carbon is expressed in US dollars of around 1995” (Tol, 2008, p. 1). 
emissions to Irish cities and rural areas (Holland and Watkiss, 2002). Thus, we implicitly assume that there are no damages to Ireland coming from sources outside Ireland.

\subsubsection{Human capital accumulation}

The adjustment for human capital accumulation $\left(A_{H}\right)$ can be expressed as:

$A_{H t}=\mu_{t}\left(\Delta H_{t} / \Delta t\right)$

where $\mu_{t}$, is the shadow price of human capital.

The World Bank's estimate of investment in human capital equals UNESCO estimates of current operating expenditures on education. This is a purely gross measure, which makes no allowance for losses in human capital. More fundamentally, it assumes that a dollar of educational expenditure translates into a dollar increase in human capital. Studies in both rich countries (Jorgenson and Fraumeni, 1992) and poor countries (Schultz, 1988) have criticized this assumption. Hanushek and Kimko (2000) show that labor-force quality differences measured on the basis of cognitive performance on tests of academic achievement (rather than on conventional measures of schooling inputs), have strong effects on growth rates.

An alternative approach to educational expenditure consists on approximating $\mu_{t}$ by the market returns to education (i.e., salaries over and above those of less educated workers). This approach is more consistent with the current consensus in the literature that expresses human capital per worker as an exponential function of years of schooling times the returns to education (see Krueger and Lindahl (2001), Woessman (2003) for reviews). In this paper we follow this approach but also analyze the robustness of the results to the use of education expenditures.

Finally, note that although neither of these approaches accounts for the health of the labor force explicitly, in (4) we are at least accounting for some of the permanent health impacts of environmental damages.

\section{Data}




\subsection{Depreciation of physical capital}

There were some discrepancies between data on gross national savings and depreciation from the WDI based on UN data, and the same data from Ireland's Central Statistics Office (CSO, 2008). We prefer the latter, direct, source; Ireland's CSO revises the entire National Accounts data series at each annual publication. Revisions may occur because of new basic data, correction of errors or methodological improvements (CSO 2009, p.31). ${ }^{13}$ The differences are partly due to the correction of errors since both sets of estimates use a common methodology, the perpetual inventory model (PIM). However, differences also arise from the World Bank method used to harmonise different countries' indicators, the so-called Atlas conversion factor. The purpose of the Atlas conversion factor is to reduce the impact of exchange rate fluctuations in the cross-country comparison of national incomes (For more information, see http://go.worldbank.org/QEIMY0ALJ0).

\subsection{Natural resource depletion}

\subsubsection{Metals and minerals ${ }^{14}$}

For the calculation of $D_{S t}$ we included zinc, lead and silver depletion. Other metals and minerals included in the WDI adjustments are either irrelevant to Ireland or their extraction was discontinued before 1995 (e.g. copper, iron pyrite). ${ }^{15}$

Zinc, lead and silver are not found as native (free) metals but they are all extracted as coproducts from the same deposits. In particular, silver is contained in lead concentrates. The main zinc-lead deposit in Ireland contains 14 million tonnes (Mt) of zinc metal (the largest in Europe, and corresponding to $1.5 \%$ of world zinc) and some $70 \mathrm{Mt}$ of zinc and lead metal.

\footnotetext{
${ }^{13}$ A number of instruments for quality assurance described in the publication "Standard Reports on Methods and Quality for National Accounts" (CSO 2009) include routinely checking the plausibility and consistency of all the statistical series through ongoing balances and cross-checks and data audits from a special Consistency Unit within the CSO.

${ }^{14}$ Most of the information on Irish minerals and metals comes from interviews and personal communications with Ben Dhonau, Principal Geologist at the Exploration and Mining Division, Department of Communications Energy and Natural Resources, Ireland. Please note that Table B1 in Appendix B summarise all the data sources used in this paper.

${ }^{15}$ We also considered but finally did not include barite and mercury (whose extraction was discontinued before 1995), and gypsum, whose production data were not available. These three resources are not considered in the WDI adjustments either.
} 
Other zinc-lead mines contain deposits of around $25 \mathrm{Mt}$. Ireland currently accounts for $6 \%$ of western world zinc mine production, and 3\% of its lead. All ore concentrates are exported.

The production of zinc has increased rapidly in recent years, from 183,500 tonnes in 1995 to 445,000 tonnes in 2005 . The production of lead averaged 49,000 tonnes per year over the period 1995-2005, with a peak of 72,200 tonnes in 2005. The production of silver was 10.5 tonnes in 2005 from a peak of 16.7 tonnes in 2000.

Since the total production of zinc, lead and silver ores is completely exported, their shadow prices were estimated by computing the ratio between the total value of exports and their quantity, using the Eurostat External Trade dataset. ${ }^{16}$

We could not obtain extraction costs for lead, zinc, and silver directly from the firms involved in their production, but experts at the Exploration and Mining Division in the Department of Communications Energy and Natural Resources provided an estimate for the average costs of joint extraction of lead, zinc and silver of $\$ 475-\$ 525$ per tonne in $2008 .{ }^{17}$ We used $\$ 500$ (the midpoint of the interval). In order to obtain a figure for each mineral's individual production costs, the $\$ 500$ figure was converted to euro ${ }^{18}$ and then distributed among the three minerals in proportion to their production for the year 2008. Then we assumed constant extraction cost over the period 1995-2008, and deflated the 2008 production costs using the index of earnings in the mining and quarrying industry to obtain estimates for the previous years. ${ }^{19}$

Finally, we assume a common lifetime for the zinc, lead and silver deposits set at 2017, the expected date of closure of the largest zinc-lead mine. ${ }^{20}$

\footnotetext{
16 This method of deriving average prices was endorsed by Ben Dhonau (see footnote 13). Data on external trade are available from Eurostat at http://ec.europa.eu/eurostat; accessed on 4 July 2008.

${ }^{17}$ Ben Dhonau: personal communication (May 2008).

${ }^{18}$ www.centralbank.ie. Data accessed on 10 July 2008.

${ }^{19}$ Data on earnings are available online at www.cso.ie/px/pxeirestat/database/eirestat/eirestat.asp and they were accessed on 7 July 2008. Data were available up to 2007. Data for 2008 were imputed by fitting an OLS regression.

${ }^{20}$ Senior Geologist Wayne Cox: personal communication (18 June 2008).
} 


\subsubsection{Energy resources ${ }^{21}$}

For the adjustment for energy depletion in $D_{S t}$ we considered natural gas and peat. We did not account for coal, as its production ceased in 1993. There is no indigenous oil production. ${ }^{22}$

Current indigenous production of natural gas accounts for less than $10 \%$ of Ireland's demand, with the balance being imported from the UK. Gas production has been decreasing from a maximum of 107,700 TJ in 1995 to 22,200 TJ in 2005.

A new gas field off the west coast was discovered in 1996 and was scheduled to start production in late 2009. It contains around 1,300,000 TJ of gas initially in place, of which $954,616 \mathrm{TJ}$ were reported as recoverable, which corresponds to $0.41 \%$ of natural gas reserves in Europe in 2005 (Energy Information Administration; see footnote 21). We computed the lifetime of natural gas by taking the ratio of expected recoverable amount in the new gas field (i.e., reserves of 954,616 TJ) to production. No data on price and cost of gas from Irish sources were available. Therefore, we used the unit rents reported by the World Bank in its website (see footnote 3).

The other indigenous resource used to produce energy, in particular electricity and domestic heating, is peat. $^{23}$ Peat is mainly produced by Bord na Mona, an Irish private company. We used their annual reports to collect information on production and lifetime and to compute the peat unit rent by multiplying their annual operating profit (per tonne of peat produced) by the percentage of revenues arising from milled peat activities in each year. ${ }^{24}$

\footnotetext{
${ }^{21}$ When otherwise not stated, information on energy resources was provided and updated as of June 2008, by Michael Hanrahan, of the Petroleum Affairs Division, Department of Communications Energy and Natural Resources, Ireland.

${ }^{22}$ Ireland remains an unexplored petroleum province. In 2005 and 2006, the government sponsored major petroleum resource assessments. These indicated a yet-to-find (unproven), risked reserve potential of 8-10 billion barrels of oil equivalent (boe) in selected basins off the west of Ireland, which would constitute a considerable $40 \%$ of total European oil reserves in 2005 (Energy Information Administration, US; http://www.eia.doe.gov/emeu/international/reserves.html, data accessed on 7 July 2008).

${ }^{23}$ Harvested milled peat is used to provide a range of products, each of which has different a price in the market. The main products are peat feedstock used for power production (about $3 \mathrm{Mt}$ per annum), peat briquettes (around 220,000 tonnes p.a.), horticultural peat, and sod turf for heating.

${ }^{24}$ This method was suggested by Charles Shier, Strategic Development Manager of Bord na Mona, personal communication (July 2008). Annual reports starting in 2002/2003 were available online at www.bnm.ie (this information was accessed on 7 July 2008). Information on previous years was either derived from the last available annual report which contains data on production from previous years or by filling the missing values by fitting OLS regressions.
} 


\subsubsection{Forests}

Over the centuries, Ireland experienced an almost complete deforestation mainly because of human activity and a deterioration of the climate. Today forests cover about $10 \%$ of land, the lowest percentage in Europe. Government policy is to bring the national forest cover to $17 \%$ by 2030 . Since 1991, most of the tree planting is carried out by private individuals with the assistance of EU grant aid. Local farmers carried out nearly $88 \%$ of all tree planting in 2004. Consequently, more than a third of all forests are in private ownership, and this proportion is rising rapidly. The average size of a forest is less than 10ha (25 acres). About half of all the forests are less than 25 years old. As of today, timber production is not commercially viable; the forest cover is simply too low to allow feasible commercial exploitation. As a result, the use value of forest changes can be approximated at zero.

Regarding the non-use value of current forests, there are not many economic valuation studies on forests in the Republic of Ireland and they focus on timber production, ignoring non-use values (e.g. Ní Dhubháin et al. 2009), or on specific values such as recreational benefits (e.g., Scarpa et al., 2000, Ní Dhubháin et al. 1994, Fitzpatrick \& Associates, 2005).

An exception is Clinch and Murphy (2001) who value the changes in forest cover, and compare positive and negative WTP for afforestation. This is mainly because forests would change the traditional view of the Irish landscape and Irish people prefer the status-quo. They show that the WTP to avoid afforestation is higher than the WTP to favour it. Bearing this in mind, not adjusting Irish national savings for the afforestation seems reasonable.

\subsection{Environmental degradation: air pollution}

The World Bank, in its computation of cross-country adjusted net savings, includes damages from $\mathrm{CO}_{2}$ and $\mathrm{PM}_{10}$ emissions. Emissions of $\mathrm{CO}_{2}$ for each country come from the Carbon Dioxide Analysis Centre (Bolt et al., 2002). In valuing $\mathrm{CO}_{2}$ emissions, the global social cost of $\$ 20 / \mathrm{tC}$ (equivalent to about $\$ 73.33 / \mathrm{tCO}_{2}$ ) in 1995 is used, by referring to the survey conducted by Fankhauser (1994 and 1995). ${ }^{25}$

We performed two alternative adjustments for $\mathrm{CO}_{2}$ emissions depending on whether we assume that the pollutee or the polluter have the property rights on the use of the atmosphere. In the first case, the case considered by the World Bank, Irish emissions are valued at their

\footnotetext{
${ }^{25}$ This represents the present value of marginal damages to crops, infrastructure, and human health over the time that emitted carbon dioxide resides in the atmosphere—over 100 years.
} 
global social cost. We used up-to-date estimates of $\mathrm{CO}_{2}$ emissions for Ireland from the Irish EPA for the period 1995-2005. ${ }^{26}$ The global social cost of $\mathrm{CO}_{2}$ emissions used in our study, $\$ 14 / \mathrm{tC}$, (equivalent to $\$ 51.33 / \mathrm{tCO}_{2}$ ) comes from a recent meta-analysis conducted on 88 estimates of marginal costs of $\mathrm{CO}_{2}$ emissions from 22 published studies (Tol, 2005).

For the second case, we estimated the damage to Ireland from global emissions following the approach in Arrow et al. (2007).First, to determine the portion of global damages due to climate change that Ireland will suffer, we utilized Nordhaus and Boyer (2000) study, which estimates the impacts of various climate change scenarios on economic sectors. We used the most conservative scenario, corresponding to a doubling of atmospheric concentrations of $\mathrm{CO}_{2}$-equivalent gases or a warming of $2.5^{\circ} \mathrm{C}$ around 2100 . Based on this likely (but simplified) scenario, Nordhaus and Boyer estimate that OECD Europe will suffer losses of around $2.5 \%$ of its GDP, while the globe will suffer damages of $1.5 \%$ of global production. In the absence of figures specific to Ireland, we take $2.5 \%$ to represent Ireland's expected damage and multiply it by its GDP and global damage by global GDP. We can then calculate the portion of global damage that Ireland will suffer as a $0.30-0.60 \%$ of global loss. Second, we took global carbon emissions data from the World Development Indicators' website (http://databank.worldbank.org/ddp/home.do) for the period 1995-2005 and multiplied them by estimates of the social cost of carbon to calculate global losses. Finally we multiplied global losses by the proportion of losses accruing to Ireland.

For $\mathrm{PM}_{10}$, due to the absence of reliable and detailed data on emissions and marginal external costs for the period 1995-2005 in Ireland, we use the numbers in the WDI. The World Bank estimates population-weighted average levels of $\mathrm{PM}_{10}$ for all cities with a population in excess of 100,000 in each country. Particulate emission damage is calculated as the WTP to reduce the risk of mortality attributable to $\mathrm{PM}_{10}$ (See footnote 3 ).

Data on $\mathrm{SO}_{2}$ and NOx emissions for 1995-2005 come from the Irish EPA as reported in Lyons et al. (2008). Marginal external costs of $\mathrm{SO}_{2}$ and $\mathrm{NOx}$ emissions for the year 2000 come from Holland and Watkiss (2002). ${ }^{27}$ Their study assesses the externalities of a tonne of

\footnotetext{
${ }^{26}$ They are available from the CSO website at http://www.cso.ie/px/pxeirestat/database/eirestat/eirestat.asp (accessed on 15 June 2008).

${ }^{27}$ Holland and Watkiss (2002) is a report specifically developed for the European Commission within the BeTa (Benefits Table database) project to estimate the marginal external costs of air pollution in Europe. The estimates for this study were calculated using the ExternE methodology (European Commission, 1998 and 1999). It follows the 'impact pathway approach' tracing emissions through dispersion and environmental
} 
$\mathrm{SO}_{2}$ emitted in Ireland on health and the effects of acidity on materials and buildings (monuments and buildings of significant cultural value are excluded) in both urban rural areas; and of a tonne of NOx emitted in Ireland on health and crop production. Note that this study does not consider the possible damages to Ireland coming from other countries. The study differentiates between the marginal costs from $\mathrm{SO}_{2}$ emissions between rural and urban areas, taking into account the difference in population density and associated exposure to the pollutants between the two. Marginal costs of $\mathrm{SO}_{2}$ emissions in rural areas are countryspecific. For Ireland the figure is $€ 2,600 /$ tonne in 2000 . The results for emissions in urban areas are however "independent of the country in which the city is located" (Holland and Watkiss, 2002, p. 13). They vary only in terms of the population of the city; for a city of 100,000 people the social cost for $\mathrm{SO}_{2}$ is fixed at $€ 6,000 /$ tonne, for bigger cities the social cost is computed by multiplying $€ 6,000$ /tonne by conversion factors provided by the study. For example, for Dublin, with a size of $1,000,000$ inhabitants, the conversion factor is 7.5 , so that social costs are $€ 45,000 /$ tonne.

We assumed constant marginal costs over the period considered and deflated the marginal costs using the Irish Consumer Price Index. ${ }^{28}$ We estimated the amount of $\mathrm{SO}_{2}$ emissions in urban and rural areas by allocating the emissions in proportion to the total household income in each Irish county as estimated by the $\mathrm{CSO}^{29}$ We considered 8 counties as urban: the counties containing the 5 urban areas of Dublin, Waterford, Limerick, Cork and Galway, plus the 3 counties in the so-called Greater Dublin Area (Meath, Kildare and Wicklow).

Finally, marginal external costs from NOx emissions in Holland and Watkiss (2002) are country-specific. For Ireland the marginal cost of a tonne of NOx is estimated to be $€ 2,800$ in 2000. Also in this case, we assumed constant marginal costs in the period considered and deflated the marginal costs with the Irish Consumer Price Index (see footnote 29).

chemistry, to exposure of sensitive receptors, physical impacts (calculated using exposure-response functions) and finally economic valuation using the willingness to pay approach. For more information see also Bickel et al. (1998).

${ }^{28}$ Data available from the CSO website at www.cso.ie/px/pxeirestat/database/eirestat/eirestat.asp (accessed on July 2008).

${ }^{29}$ Available online in the National Accounts series at www.cso.ie/px/pxeirestat/database/eirestat/eirestat.asp (date accessed: 15 June 2008). 


\subsection{Human capital accumulation}

We derived the annual value of human capital accumulation by multiplying the annual predicted earnings at each educational level by the estimated annual change in the number of people in the labour force by educational attainment.

Barret et al. (2002) estimate the returns to education relative to primary education for Ireland for the years 1987, 1994 and 1997. They regress individual earnings on different levels of educational qualification (university degree, third degree diploma, high school, secondary) and other controls for each year and age band (young, middle-aged, old). The estimated returns on education are significantly different across education levels, but they do not significantly vary over time. Therefore, we take the average (for the years 1994 and 1997 ) as the (constant) return on education from 1995-2005. Overall, returns to education are large: for example, those with a university degree earn, on average, 94\% more than those who only obtained primary education.

In order to get a monetary value, we multiplied the yearly earnings of people with only primary education times $(1+$ coefficient on the return on education) for each level of educational attainment above primary education. Yearly earnings of those with primary education were calculated as the hourly wage of people with primary education, times the average number of hours worked per week times $52 .^{30}$

We estimated the annual change in the number of people in the labour force by educational attainment by taking the difference among the absolute number of persons in the labour force at each level of educational attainment from various years of the census of population (CSO, 1992; CSO, 1997; CSO, 2003; CSO, 2007), and fitting a linear trend for the years with missing data.

\section{Results}

We plug in our estimates of $G N S, D_{K}, D_{S}, D_{E}$, and $A_{H}$ into equation (3) to arrive at our bottom-line estimates of genuine savings. Since $D_{S}$ was computed for three different interest

\footnotetext{
${ }^{30}$ Data on hourly wages of people with primary education are published online by the Irish Department of Education and Science at http://www.cso.ie/px/des/database/des/des.asp (accessed on 15 June 2008). Average hours worked per week were available for the period 1996-2005 at http://www.cso.ie/px/pxeirestat/database/eirestat/Earnings\%20Employment\%20and\%20Productivity\%20in\%20I ndustry/Earnings\%20Employment\%20and\%20Productivity\%20in\%20Industry.asp. Information accessed on 15 June 2008). The missing value for 1995 was imputed with a linear OLS method.
} 
rates (2, 4 and 6\%), Figure 1 presents three estimates of genuine savings. ${ }^{31}$ Recall from Sections 2.2.3 and 3.3 that damages from $\mathrm{CO}_{2}$ emissions can be computed using two different methods. In Panel A of Figure 1, Irish $\mathrm{CO}_{2}$ emissions are valued at their global social cost (i.e. the pollutee is assumed to have the property rights on the use of the atmosphere). In panel $\mathrm{B}, \mathrm{CO}_{2}$ damages to Ireland from global emissions are considered (i.e. property rights lie with the polluter). It turns out that both methods return similar measures of depreciation. The first method, however, yields slightly larger adjustments at the beginning of the period (i.e., when GS are negative, see Figure 1). Therefore, for conservative reasons, we focus on the estimates of GS using the second method, i.e., adjusting for the damages to Ireland from global emissions. ${ }^{32}$ Note that the use of different interest rates does not make a big difference either. The adjustment for natural resource depreciation in Ireland is negligible in comparison to the much larger adjustment from environmental degradation for whose calculation interest rates are implicit. In what follows we will refer to the genuine savings figures computed using $r=4 \%$, i.e., the middle value, when not otherwise stated, for simplicity of exposition.

A striking feature of Figure 1 is the negative genuine savings for three years in a row: from 1995 to 1997. Previous studies consistently show that developed countries do not seem to be affected by sustainability problems (see e.g., Pearce and Atkinson, 1993; Dasgupta, 2001; Arrow et al., 2004; 2007). To the extent of our knowledge, Hanley et al. (1999) is the only previous study that finds negative genuine savings for a developed, economy, Scotland, over the period 1980-1994. They argue that their results are a direct consequence of contingent macroeconomic variables, such as the high price and high extraction rate of oil. The volatility in the oil price is related to market imperfections and politics rather than to actual social productivity. They updated their figures in one recent study where they show positive values in both genuine savings and green net national product for Scotland over the period 1992-1999 (Pezzey et al., 2006). Negative genuine savings in our study for Ireland are not driven by volatile prices of natural resources (which would not be able to adequately capture shadow values) but by externalities arising from air emissions.

Figure 1 also shows the evolution of GNP over the period 1995-2005. Although the growth of GNP could be due to factors not picked up by components of the genuine savings indicator, both GNP and GS show a strong positive trend. Interestingly, however, negative

\footnotetext{
31 Current values were converted into constant values at 2000 prices by using the implicit GNP deflator (www.cso.ie, accessed July 2008).The actual numbers are presented in Table C1 in Appendix C.

${ }^{32}$ Figure $\mathrm{C} 1$ in the appendix compare the two methods of computing $\mathrm{CO}_{2}$ adjustments.
} 
savings were being experienced when real GNP was growing by a considerable $8-10 \%$ per annum. After 1997 genuine savings have always been positive and increasing considerably (e.g., in 2005 the genuine savings were more than 11 times the ones reported in 1998).

\section{- Figure 1 about here -}

A decomposition of the genuine savings indicator into its elements, net national savings, market resource depletion, environmental degradation and human capital accumulation, can shed some light into this result. This is shown in Figure 2. From Figure 2 it is evident that the bottom-line genuine savings figure is driven by two main components: net national savings, which reflect the amount of total output set aside for net investments in human-made capital, and the environmental degradation arising from $\mathrm{CO}_{2}, \mathrm{SO}_{2}, \mathrm{NOx}$ and $\mathrm{PM}_{10}$ emissions into the atmosphere. These two forces act in opposite directions. Negative genuine savings over 19951997 was driven by the high social external costs of emissions of pollutants which was not compensated for by net national investments in other forms of capital. However the latter have increased considerably during the period (10\% p.a.) indicating that the negative effects arising from air emissions externalities (whose value is actually decreasing over time) are being compensated for by physical and human capital accumulation. Investments in human capital follow the same trend as net national savings. The population in the labour force with higher levels of education (i.e., third level) was low during the first years of the period considered, while increasing almost threefold in the following years. The contribution of changes in the value of human capital to positive genuine savings is therefore evident, although smaller than the net investments in man-made capital. As expected for a country that does not depend on its own natural resources, the value of depreciation from market natural resources is small.

In Figure 3 we look at environmental degradation in more detail because it is evident that it is playing a dominating role in our computation of genuine savings. The overall trend shows that the external costs of air pollution are decreasing after 1998. A decomposition of the external costs shows that $\mathrm{SO}_{2}$ emissions are driving the results. The emissions of $\mathrm{SO}_{2}$ in Ireland are decreasing since 1998 at a rate of $12 \%$ p.a., which contributes to positive values of genuine savings in recent years. These reductions are driven by a variety of economic structural changes and environmental policies, including a substantial decrease in the sulphur content of fuel oil and gas-oil, the use of low-sulphur coal at power stations, the increased use 
of natural gas in electricity generation and a shift from solid fuels to natural gas and kerosene in the residential sector. Irish $\mathrm{CO}_{2}$ emissions have increased by $2.8 \%$ p.a. during the period considered and the negative externalities by $10.7 \%$ p.a. ${ }^{33}$ NOx emissions have declined from their level in 1995, thanks to policy interventions. Catalyst controls in cars and heavy duty vehicles were implemented, although these measures were probably offset by the increase in road traffic. A large part of the reduction after 2000 is due to technological controls (EPA Ireland, 2002; 2003).

\section{- Figures 2 and 3 about here -}

\subsection{Comparison with World Bank Estimates}

Figure 4 illustrates the comparison between our estimates of genuine savings and those published by the World Bank. Our estimates are consistently lower than the World Bank's. Moreover, according to the Bank's estimates, Ireland experienced positive genuine savings every year between 1995 and 2005, while our estimates for 1995, 1996 and 1997 (computed at $r=4 \%$ ) are negative, indicating sustainability problems. The main reason for this difference is that we have extended the number of pollutants; the World Bank only reports external costs for $\mathrm{CO}_{2}$ and $\mathrm{PM}_{10}$ emissions. In recent years, the two series follow the same trend, with positive and increasing values of genuine savings.

\section{- Figure 4 about here -}

To further investigate the difference between the two series, Figure 5 plots the differences among the four components of genuine savings; net national savings, market resource depreciation, environmental degradation and human capital accumulation.

The net national savings reported by the World Bank are larger than ours at the beginning of the period. The value of changes in human capital computed using current education expenditure is also larger than our estimates based on returns to education. Both elements contribute to the genuine savings figures reported by the World Bank being more positive than ours. On the other hand, the value of market resource depreciation computed by the Bank using the net-price method is always larger in absolute terms than the depreciation

${ }^{33}$ When considering the alternative method of valuing adjustment from $\mathrm{CO}_{2}$ externalities, $\mathrm{CO}_{2}$ damages increased by $6.7 . \%$ p.a. See Figure C1 in Appendix C. 
computed using the net present value method, which contributes to lower genuine savings. For the period 1998-2005 these differences almost offset each other. However, our corrections for environmental degradation are always larger than the Bank's, and the difference is large, leading to lower genuine savings. Extending the set of pollutants in our accounts to include $\mathrm{SO}_{2}$ and NOx is critical in driving this result.

\section{- Figure 5 about here -}

\subsection{Sensitivity analysis}

The comparison with the World Bank estimates suggests some robustness checks for our estimates, shown in Table 1. Table 1 presents genuine savings as a percentage of gross national income (genuine savings rates henceforth) computed under different assumptions. The last column of Table 1 shows the World Bank estimates so that our estimates can be compared with them directly.

The first column shows genuine savings rates for our benchmark indicator (i.e., with $r=$ $4 \%$ and $\mathrm{CO}_{2}$ damages assuming property rights lie with the polluter). The second column of Table 1 shows genuine savings rates when human capital is computed using education expenditures instead of the market return to education. The data of education expenditures refers to all the expenditures (capital and current) for institutions aided by the Department of Education and Science (which accounts for $97 \%$ of the total number of educational institutions in Ireland). ${ }^{34}$ Compared to the first column, the numbers in this second column are larger but genuine savings remain robustly negative in 1995, while the rates in 1996 are negative but close to zero and in 1997 they are positive.

The third and fourth column of Table 1 report genuine savings estimates when the social costs of $\mathrm{CO}_{2}$ emissions are allowed to vary. Our estimate of the global social cost of carbon dioxide, \$14/tC, was derived from Tol (2005) who combines 103 estimates of social cost of carbon from 28 studies to form a probability density function with a median of $\$ 3.8 / \mathrm{tC}$, a mean of $\$ 14 / \mathrm{tC}$, and a $95^{\text {th }}$ percentile of $\$ 67 / \mathrm{tC}$. In a recent paper Weitzman (2008) argues that the economic consequences of fat-tailed (non-Gaussian) structural uncertainty, along with uncertainty about high-temperature damages, should play a huge role in evaluating policies for climate change. In other words, catastrophic events may be rare but are possible

\footnotetext{
${ }^{34}$ This data can be found online at www.education.ie (accessed 15 June 2008).
} 
and their consequences are understated by current models. This would suggest we should consider the $95^{\text {th }}$ percentile of the probability density function as a possibility. Moreover, a new meta-analysis by Tol (2008) suggests higher values of median and mean social cost of $\mathrm{CO}_{2}$ of $\$ 13 / \mathrm{tC}$ and $\$ 19 / \mathrm{tC}$, respectively, and a slightly lower value of $95^{\text {th }}$ percentile of $\$ 63 / \mathrm{tC}$ (see also Hepburn, 2007). Column three shows genuine savings rates computed using higher values for the social cost of carbon: $\$ 20 / \mathrm{tC}$ - which is the number of reference in a number of studies and at the World Bank, see Fankhauser (1994 and 1995) and \$67/tCO (which corresponds to the 95th percentile in Tol, 2005) in column 4. In both cases, the assumption of property rights lying with the pollutee is used. As we would expect, using $\$ 20 / \mathrm{tC}$ does not make much of a difference, while using $\$ 63 / \mathrm{tC}$ changes the scenario quite a lot resulting in negative GS rates from 1995 to 2002. Note that if the missing negative externalities would be bigger than 1-2.6\% of GNI in 2003-2005, the conclusion would be that Ireland is on an unsustainable path for all the period considered.

Because of the importance of $\mathrm{SO}_{2}$ in driving our results, columns five and six of Table 1 show the genuine savings rate computed using different assumptions regarding $\mathrm{SO}_{2}$ emissions. In column five, we allocate the emissions among rural and urban areas by population instead of income using data from the Census of population (CSO, 2007; CSO, 1992; CSO, 1997). To be more conservative we assumed as urban population only the population living in Dublin. The new estimates show genuine savings still being negative in 1995 and 1996 (albeit close to zero in 1996).

The estimates of social costs of pollution for Ireland in the study of reference (Holland and Watkiss, 2002), $€ 2,600$ /tonne for $\mathrm{SO}_{2}$ in rural areas and $€ 2,800 /$ tonne for $\mathrm{NOx}$, are lower than the European average $\left(€ 5,200 /\right.$ tonne for $\mathrm{SO}_{2}$ in rural areas, $€ 4,200 /$ tonne for $\left.\mathrm{NOx}\right)$ and than the ones attributed to the $\mathrm{UK}\left(€ 4,500 /\right.$ tonne for $\mathrm{SO}_{2}$ in rural areas, $€ 2,600 /$ tonne for NOx). However the estimates are larger than numbers for $\mathrm{SO}_{2}$ damage from a recent study by Pezzey et al. (2006) for the UK and Scotland. In column seven we apply the estimates from Pezzey et al. (2006). ${ }^{35}$ The marginal costs for $\mathrm{SO}_{2}$ are $£ 6,597 /$ tonne expressed in 1999 pounds sterling (which corresponds roughly to $€ 10,824 /$ tonne in 2000), while marginal costs for $\mathrm{NO}_{2}$ (not NOx) are around $£ 2,100 /$ tonne (circa $€ 3,445 /$ tonne in 2000). The main difference between our estimates and those in Pezzey et al. (2006) is that they do not consider differential impacts of $\mathrm{SO}_{2}$ in rural and urban areas. Accounting for population density and its

\footnotetext{
${ }^{35}$ Note that Pezzey et al. (2006) provides estimates for the marginal cost of $\mathrm{NO}_{2}$ instead of NOx. Data on $\mathrm{NO}_{2}$ emissions are from Lyons et al. (2008).
} 
influence on exposure and, ultimately, on impacts is fundamental in Holland and Watkiss (2002) and considered important also by other recent studies on marginal costs of pollution (e.g., AEA, 2005). The genuine savings rates in column seven are always positive over the period of interest. However, they are consistently lower than the World Bank's.

\section{- Table 1 about here -}

\section{Conclusions}

In this paper we compute genuine savings indicators for Ireland, a rich, non-resourcedependent economy, for the period 1995-2005. We build on and improve the existing estimates of genuine savings for Ireland produced by the World Bank in four ways. First, we use Irish data sources, limiting the use of international averages. The collection of data from Irish sources was more difficult than envisaged; some of the data were confidential and not accessible. Thanks to the help of local experts we could obtain crucial information about unit rents of tradable market resources and we are confident that our data are of higher quality than those used by the Bank. Second, our estimates use the present value method for the valuation of the depreciation of tradable natural resources. This method is endorsed by national and international statistical agencies (see UN, 1993; Common and Sanyal, 1998) and preferred to the net-price method used by the World Bank. Third we value human capital accumulation using the returns to education. This method is favoured by the literature over the education expenditure approach. Fourth we expand the valuation of environmental degradation by including estimates of $\mathrm{SO}_{2}$ and NOx external costs. Not surprisingly, for a rich economy like Ireland that does not depend on its own natural resources, this last change has the biggest influence in our results.

In sharp contrast with previous literature, when the computation of genuine savings is extended to include the value of environmental degradation caused by air pollution, we show that a developed economy can experienced negative genuine savings. All but one of the scenarios presented in this paper show negative genuine savings for Ireland for at least two years, 1995 and 1996, of the period considered. This result is worrying if we consider that the emissions and external costs $\mathrm{SO}_{2}$ and $\mathrm{NOx}$ in Ireland are low relative to other countries when using the same study of reference (Holland and Watkiss, 2002) and suggests that other jurisdictions may be experiencing substantially lower genuine savings rates than those published by the World Bank. Moreover, a scenario that allows for low-probability high- 
impact climate changes leads to negative genuine savings for most of the years considered. When using marginal costs of $\mathrm{SO}_{2}$ and $\mathrm{NOx}$ for the UK and Scotland, genuine savings are positive for all the years but they remain substantially lower than the World Bank estimates. Finally, our results are robust to the use of different interest rates, different proxies for human capital accumulation and different property rights on the use of the atmosphere regarding $\mathrm{CO}_{2}$ emissions.

Our study suggests that even a non-resource dependent economy can alarmingly focus on current rates of consumption at the expense of future productive capacity. The fact that Ireland has experienced in the past such periods does not rule out the possibility that it can do so also in the future if adequate investments in human and man-made capital are not set aside. The good news is that by implementing appropriate environmental policy, such as control of $\mathrm{SO}_{2}$ emissions, and by investing in other forms of capital, such as infrastructure and human capital, Ireland was able to turn things around. However, it should be noted that positive genuine savings at a given point in time are not a guarantee of sustainability and that, although extended, our genuine savings indicator is still imperfect and misses components of natural capital, such as biodiversity and environmental quality other than air pollution, that may affect Ireland's productive capacity and well-being. 


\section{References}

AEA (2005). Damages per tonne emission of PM2.5, NH3, SO2, NOx and VOCs from each EU25 Member State (excluding Cyprus) and surrounding seas European Commission DG Environment

Arrow, K., Dasgupta, P., Goulder, L., Daily, G., Ehrlich, P., Heal, G., Simon, L., Maler, K.G., Schneider, S., Starrett, D. and Walker, B. (2004). Are We Consuming Too Much? The Journal of Economic Perspectives 18, 147-172.

Arrow, K., Dasgupta, P. and Mäler, K.-G. (2003). Evaluating Projects and Assessing Sustainable Development in Imperfect Economies. Environmental and Resource Economics 26, 647-685.

Arrow, K. J., Dasgupta, P., Goulder, L. H., K., M. and Oleson, K. (2007). China. the U.S. and sustainability: perspectives based on comprehensive wealth. Department of Economics, Standford University.

Asheim, G. B. (1994). Net National Product as an Indicator of Sustainability. Scandinavian Journal of Economics 96(2): 257-65.

Asheim, G. B. (2003) Green National Accounting for Welfare and Sustainability: A Taxonomy of Assumptions and Results. Scottish Journal of Political Economy 50(2):113-130.

Atkinson, G. and Hamilton, K. (2007). Progress along the path: evolving issues in the measurement of genuine saving. Environmental and Resource Economics 37, 43-61.

Barrett, A., FitzGerald, J. and Nolan, B. (2002). Earnings inequality, returns to education and immigration into Ireland. Labour Economics 9, 665-680.

Bickel, P., Schmid, S., Krewitt, W. Friedrich, R., Watkiss, P, Collings, S., Holland, M.R., Pilkington, A., Hurley, F., Donnan, P., Landrieu, G., Eyre, N., Navrud, S., Rabl, A., Spadaro, J., Assimacopoulos, D., Vossiniotis, G., Fontana, M. Frigerio, M. and Dorland, K. (1998) External Costs of Transport. R. Friedrich, P. Bickel and W. Krewitt (eds.) Published by IER, Universitat Stuttgart, Band 46.

Bolt, K., Mampite, M., Clemens, M. (2002). Manual for calculating adjusted net savings. Environment Department, World Bank.

Clinch, J. P. (2001). Reconciling Rapid Economic Growth and Environmental Sustainability in Ireland. Journal of the Statistical and Social Inquiry Society of Ireland XXX, 159226.

Clinch, J. P. and Murphy, A. (2001). Modelling Winners and Losers in Contingent Valuation of Public Goods: Appropriate Welfare Measures and Econometric Analysis. The Economic Journal 111, 420-443. 
Common, M. S. and Sanyal, K. (1998). Measuring the depreciation of Australia's nonrenewable resources: a cautionary tale. Ecological Economics 26, 23-30.

CSO (1992). Census 1991. (Central Statistics Office) Dublin, Ireland: Stationary Office.

CSO (1997). Census 1996. (Central Statistics Office) Dublin, Ireland: Stationary Office.

CSO (2003). Census 2002. (Central Statistical Office) Dublin, Ireland: Stationary Office.

CSO (2007). Census 2006. (Central Statistical Office) Dublin, Ireland: Stationary Office.

CSO (2008). National Income and Expenditure. Dublin: Stationary Office.

CSO (2009). Standard Report on Methods and Quality (v1) for National Accounts. http://www.cso.ie/surveysandmethodologies/surveys/accounts/documents/pdf_docs/n ational_accounts_quality_report.pdf

Dasgupta, P. (2001). Human well-being and the natural environment. Oxford and New York: Oxford University Press.

Dasgupta, P. (2009) The Welfare Economic Theory of Green National Accounts. Environmental and Resource Economics 42:3-38.

Dasgupta, P. and Mäler, K.-G. (2000). Net National Product, Wealth, and Social Well-Being. Environment and Development Economics 5, 69-93.

El Serafy, S. (1989). The proper calculation of income from depletable natural resources. In Environmental accounting for sustainable development: a UNDP-World Bank Symposium(Eds, Yusuf, A., El Serafy, S. and Lutz, E.). Washington DC: World Bank, $10-18$.

EPA Ireland (2002). Air Quality Monitoring Annual Report 2001. Dublin, Ireland: Environmental Protection Agency.

EPA Ireland (2003). Air quality and emissions to air. Wexford, Ireland: Environmental Protection Agency.

European Commission (1998) DGXII (JOULE Programme) Externalities of Energy, ExternE Project, Report Number 10, National Implementation. Edited by CIEMAT. Report available from European Commission DG Research.

European Commission (1999) DGXII (JOULE Programme) Externalities of Energy, ExternE Project, Report Number 7, Methodology: Update 1998. Holland, M.R. and Forster, D. (eds.). Report available from European Commission DG Research. 
Fankhauser, S. (1994). The economic costs of global warming damage: A survey. Global Environmental Change 4, 301-309.

Fankhauser, S. (1995), Valuing Climate Change - The Economics of the Greenhouse, 1 edn, EarthScan, London.

Ferreira, S. and Vincent, J. R. (2005). Genuine savings: leading indicator of sustainable development? In Economic Development and Cultural Change, Vol. 53. 737-754.

Fitzpatrick, and Associates. 2005. Economic Value of Trails and Forest Recreation in Ireland. Coillte and The Irish Sports Council

Hamilton, K. (1994). Green Adjustments to GDP. Resources Policy 20, 155-168.

Hamilton, K. (1996). Pollution and Pollution Abatement in the National Accounts. Review of Income and Wealth 42, 13-33.

Hamilton, K. and Clemens, M. (1999). Genuine Savings Rates in Developing Countries. World Bank Economic Review 13, 333-56.

Hamilton, K. and Atkinson, G. (1996) Air pollution and green accounts. Energy Policy 24:675-684.

Hanley, N. Moffatt, I. Faichney, R. and Wilson, M. (1999) Measuring sustainability: a time series of indicators for Scotland, Ecological Economics, 28:55-73.

Hanushek, E.A. and D. D. Kimko (2000) Schooling, Labor-Force Quality, and the Growth of Nations. American Economic Review 90(5):1184-1208.

Hartwick, J. M. (1977). Intergenerational Equity and the Investing of Rents from Exhaustible Resources. American Economic Review 67, 972-974.

Hartwick, J. M. and Hagemann, A. (1993). Economic depreciation of mineral stocks and the contribution of El Serafy. In Toward Improved Accounting for the Environment(Ed, Lutz, E.). Washington D.C.: The World Bank.

Hepburn, C. (2007). Review for Economics of the social cost of carbon: trends, outliers and catastrophes. Referee Report for 'Economics, Open-access, Open-accessment EJournal.

Holland, M. and Watkiss, P. (2002). Benefits table database: estimates of the marginal external costs of air pollution in Europe. Bruxelles: European Commission DG Environment. 
Jorgenson, D. W. and Fraumeni, B. M. (1992). The Output of the Education Sector. In Output Measurement in the Service Sectors(Ed, Griliches, Z.). Chicago: University of Chicago Press.

Krueger, A., Lindahl, M. (2001). Education for growth: Why and for whom? Journal of Economic Literature 39, 1101-1136.

Lane, P. R. and G. M. Milesi-Ferretti (2007) "The External Wealth of Nations Mark II" , Journal of International Economics 73, 223-250.

Lyons, S., Mayor, K. and Tol, R. S. J. (2008). Environmental Accounts for the Republic of Ireland: 1990-2005. ESRI Working Paper No. 223.

Neumayer, E. (2000). Resource Accounting in Measures of Unsustainability: Challenging the World Bank's Conclusions. Environmental and Resource Economics 15, 257-278.

Ní Dhubháin, Á., J. Gardiner, J. Davies, G. Hutchinson, S. Chilton, K. Thomson, D. Psaltopoulos, and C. Anderson. 1994. The Socio-economic Impact of Afforestation on Rural Development, Contract No. 8001-CT90-0008. Final Report to the European Union

Ní Dhubháin, A., M.C. Flécharda, R. Moloneyb and D. O'Connor (2009). Assessing the value of forestry to the Irish economy: An input-output approach. Forest Policy and Economics 11(1): 50-55

Nordhaus, W.D., Boyer, J.G., 2000. Warming the World:economic models of global warming. The MIT Press, Cambridge.

Nordhaus, W. D. (2000). New Directions in National Economic Accounting. American Economic Review 90, 259-263.

Pandey, K., Bolt, K., Deichman, U., Hamilton, K., Ostro, B. and Wheeler, D. (2005). The Human Cost of Air Pollution: New Estimates for Developing Countries. Development Research Group and Environment Department World Bank, Wahington DC.

Pearce, D. and Atkinson, G. (1993). Capital theory and the measurement of sustainable development: an indicator of 'weak' sustainability. In Ecological Economics, Vol. 8. 103-108.

Pearce, D. W. and Ulph, D. (1998). A Social Discount Rate for the United Kingdom. In Economics and environment: Essays on ecological economics and sustainable development(Ed, Pearce, D.). Cheltenham, U.K. and Northampton, Mass: Edward Elgar, 268-285.

Perman, R., Ma, Y., McGilvray, J. and Common, M. S. (2003). Natural resource and environmental economics. Harlow, Essex: Pearson Education. 
Perrings, C. and Vincent, J. R. (2003). Green Accounting and the Sustainability of Economic Development. In Natural resource accounting and economic development: Theory and practice. Cheltenham, U.K. and Northampton, Mass.: Edward Elgar, 1-21.

Pezzey, J. C. V., Hanley, N., Turner, K. and Tinch, D. (2006). Comparing augmented sustainability measures for Scotland: Is there a mismatch? Ecological Economics 57, 60-74.

Pezzey, J.C.V. and M.A. Toman (2002) Progress and Problems in the economics of sustainability. In Tietenberg, T., Folmer, H., eds. International Yearbook of Environmental and Resource Economics 2002/3 Edward Elgar, Cheltenham, pp.165232.

Pezzey, J.C.V. and M. A. Toman (2005) Sustainability and its Economic Interpretations. In Simpson, D.R., M.A. toman and R.U. Ayres, eds, Scarcity and Growth Revisited: Natural resources and the Environment in the New Millennium (pp:121-141). RFF Press: Washington D.C.

Repetto, R., Magrath, W., M., W., Beer, C. and Rossini, F. (1989). Wasting assets: natural resources in the national accounts. Washington DC: World Resource Institute.

Scarpa, R., W.G. Hutchinson, S.M. Chilton, and J. Buongiorno. 2000. Importance of forest attributes in the willingness to pay for recreation: a contingent valuation study of Irish forests. Forest Policy and Economics 1:315-329.

Schultz, T. P. (1988). Education Investments and Returns. In Handbook of Development Economics, vol. 1(Ed, Srinivasan, H. C. a. T. N.). Amsterdam: North-Holland.

Seroa da Motta, R. and Ferraz do Amaral, A. C. (2000). Estimating timber depreciation in the Brazilian Amazon. Environment and Development Economics 5, 129-142

Simpson, R. D., Toman, M. A. and Ayres, R. U. (2005). Scarcity and growth revisited : natural resources and the environment in the new millennium. Washington, DC: Resources for the Future.

Solow, R. M. (1986). On the Intergenerational Allocation of Natural Resources. Scandinavian Journal of Economics 88, 141-149.

Tol, R. S. J. (2005). The marginal damage costs of carbon dioxide emissions: an assessment of the uncertainties. Energy Policy 33, 2064-2074.

Tol, R. S. J. (2008). The Social Cost of Carbon: Trends, Outliers and Catastrophes. Economics: The Open-Access, Open Assessment E-Journal 1.

UN (1993). System of National Accounts. New York: United Nations. 
Weitzman, Martin L. 1976. "On the Welfare Significance of National Product in a Dynamic Economy.” Quarterly Journal of Economics 90 (February): 156-62.

Weitzman, M. L. (2008). On modeling and interpreting the economics of catastrophic climate change. Review of Economics and Statistics.

Woessmann, L. (2003) "Specifying human capital" Journal of Economic Surveys 17(3):23970.

World Bank (2006) "Where is the Wealth of Nations? Measuring Capital for the XXI century." World Bank: Washington.

Zerbe, R. and Dively, D. (1994). Benefit-cost analysis in theory and practice. New York: Harper Collins College Publishers. 


\section{Figures and Tables}

\section{Panel A}

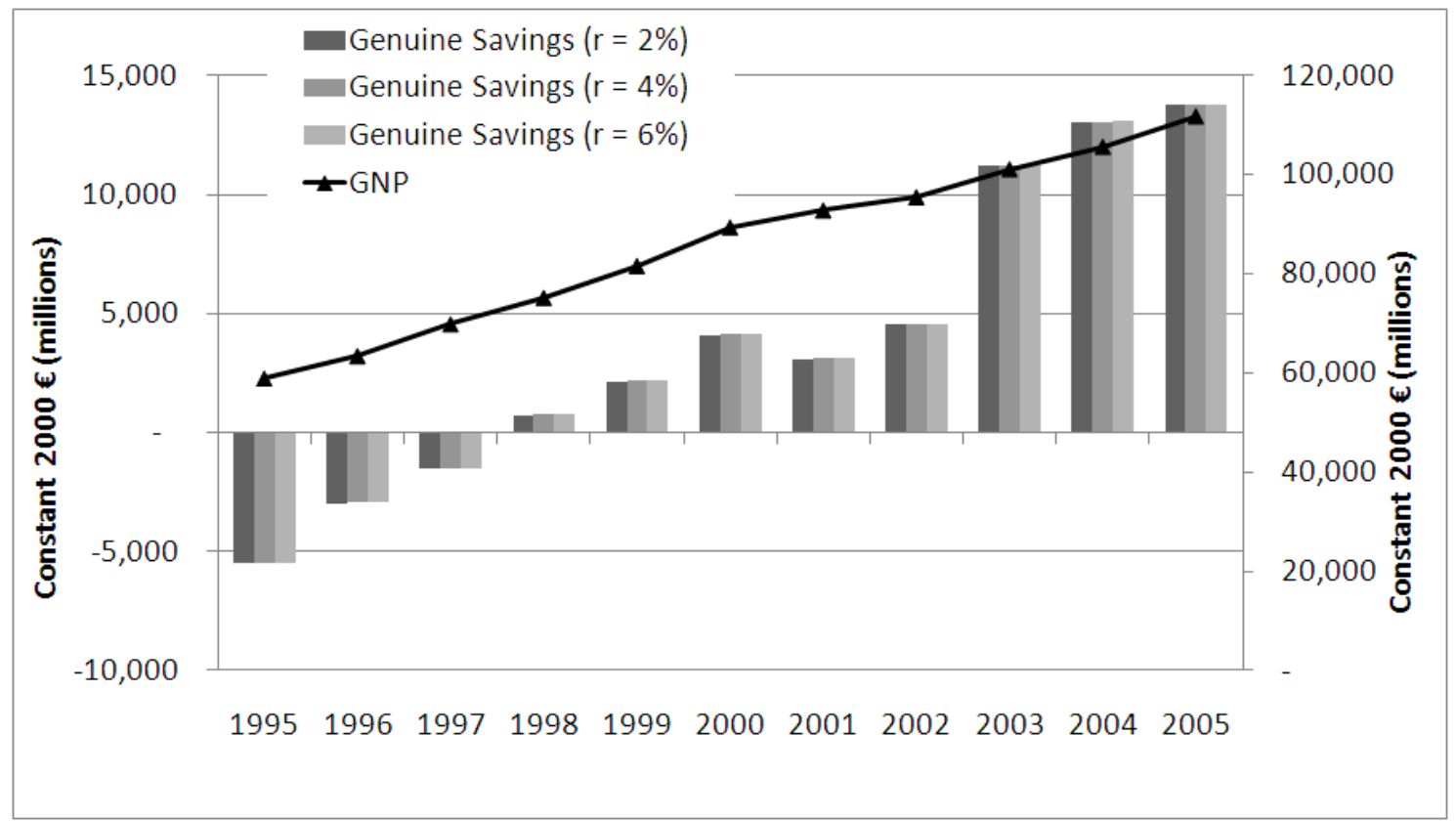

\section{Panel B}

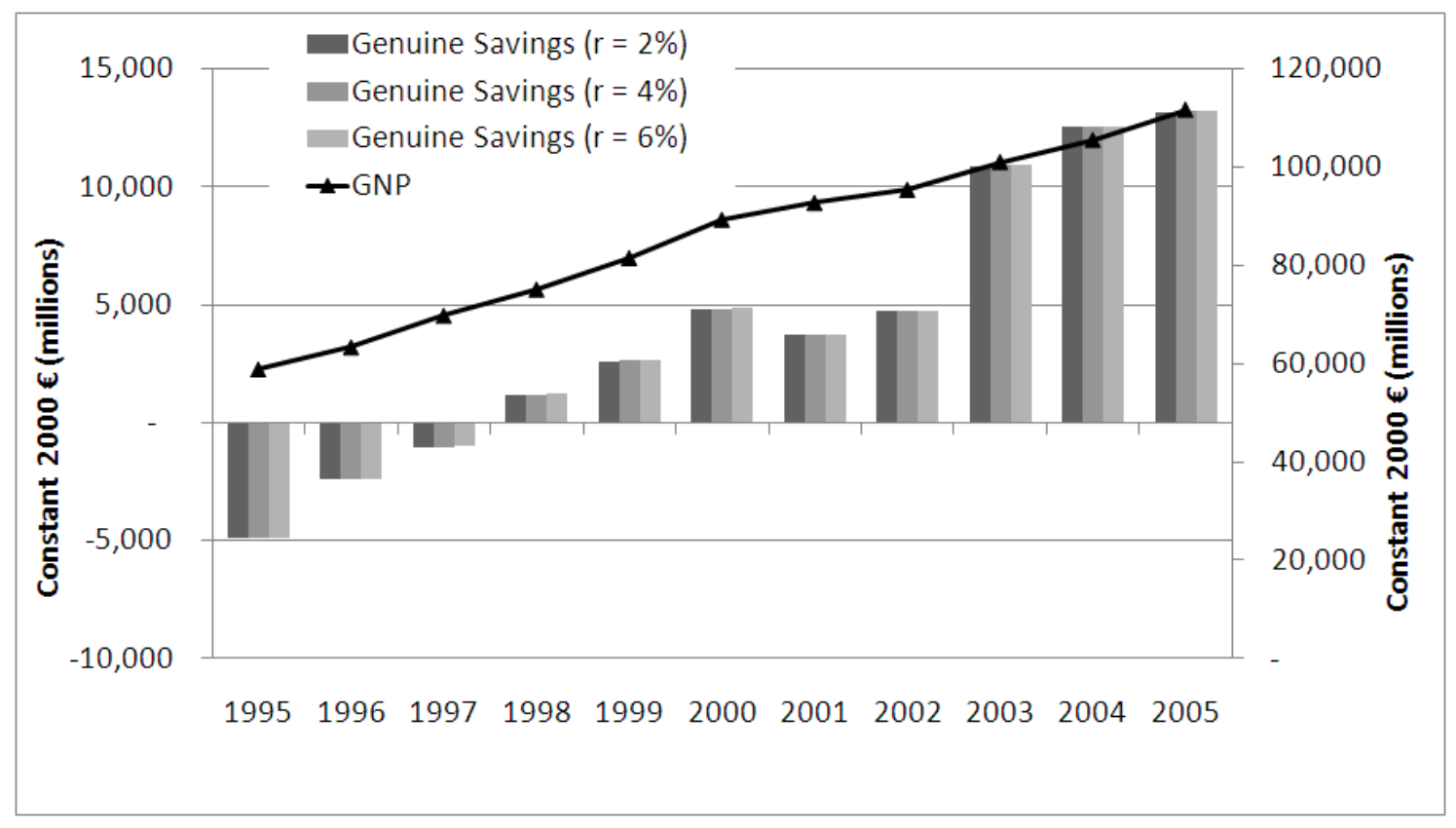

Figure 1 Genuine savings vs. Gross National Product in Ireland (1995-2005)

Note: the vertical axis on the left refers to genuine savings, while the vertical axis on the right refers to GNP. In Panel A, Irish $\mathrm{CO}_{2}$ emissions are valued at the global social cost of carbon and subtracted from net national savings (i.e. property rights to the atmosphere lie with the pollutee).In Panel $\mathrm{B}, \mathrm{CO}_{2}$ damages to Ireland from global emissions are considered (i.e. property rights to the atmosphere lie with the polluter). For details, see Sections 3.3 and 2.2.3. Source: GNP from the Central Statistics Office (www.cso.ie), Genuine savings are from authors' calculations. 


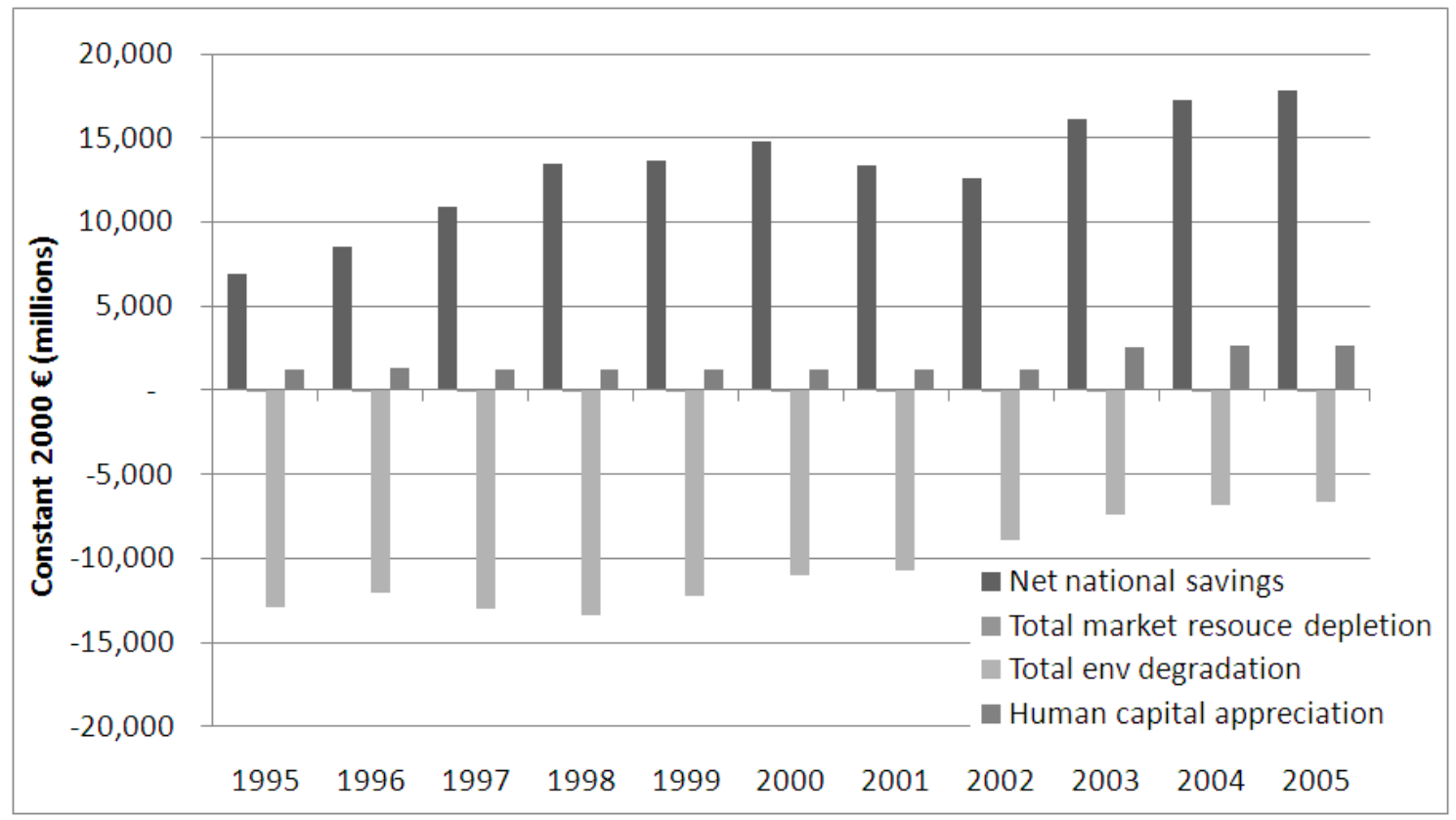

Figure 2 Genuine savings components (1995-2005) 


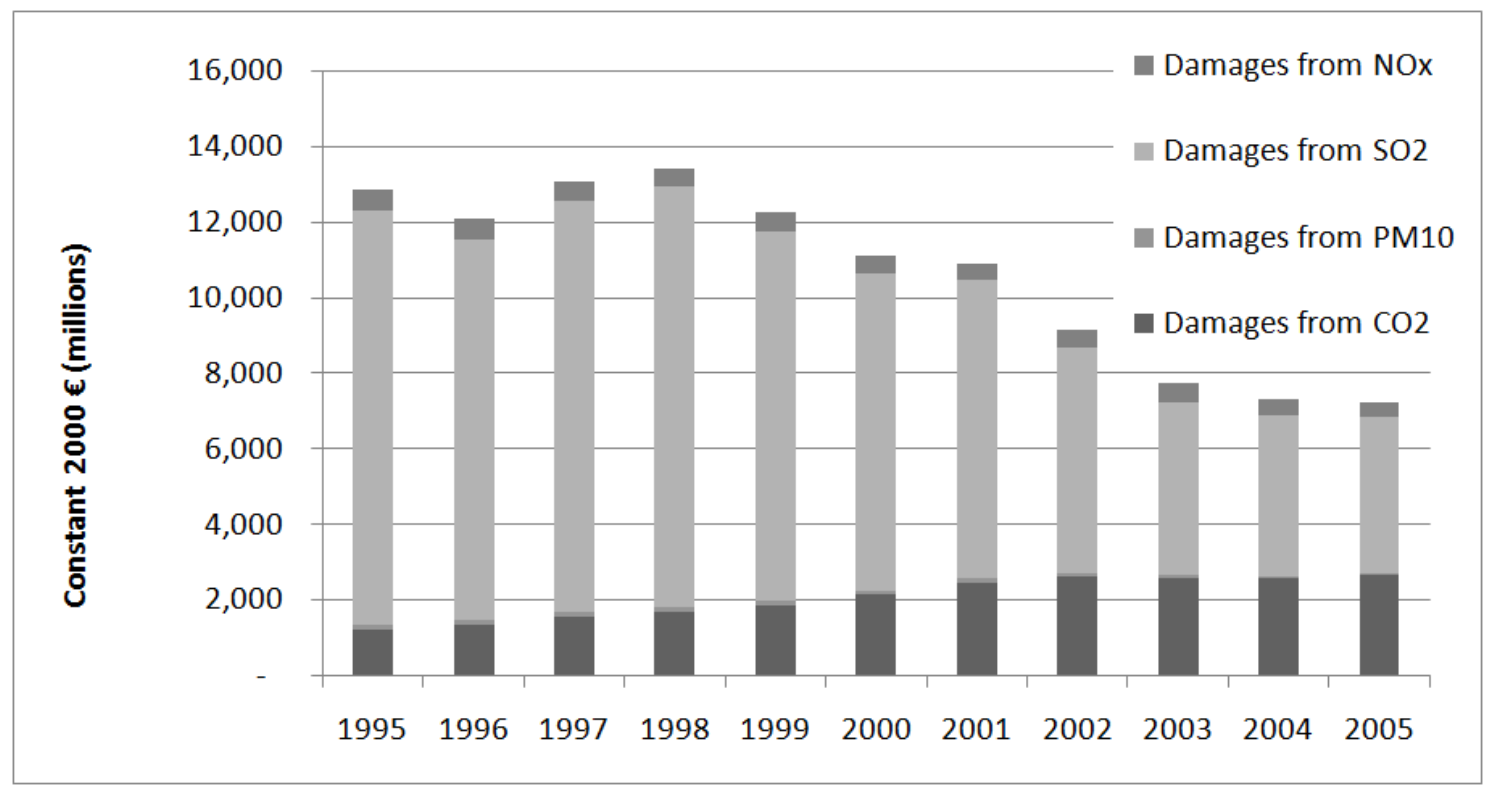

Figure 3 Environmental degradation arising from emissions into air (1995-2005)

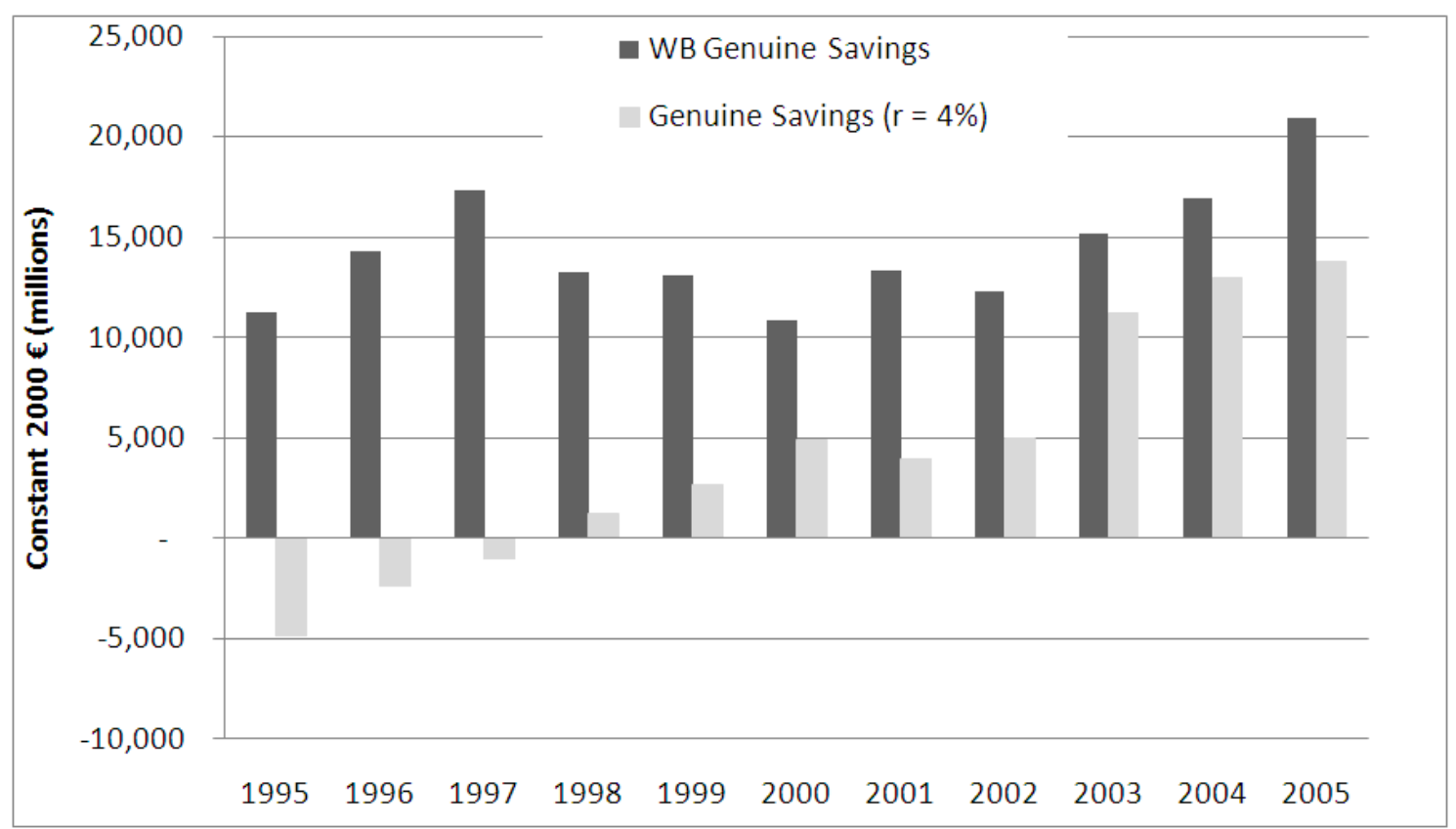

Figure 4 Comparison of genuine savings estimates: World Bank (WB) estimates vs. our estimates 


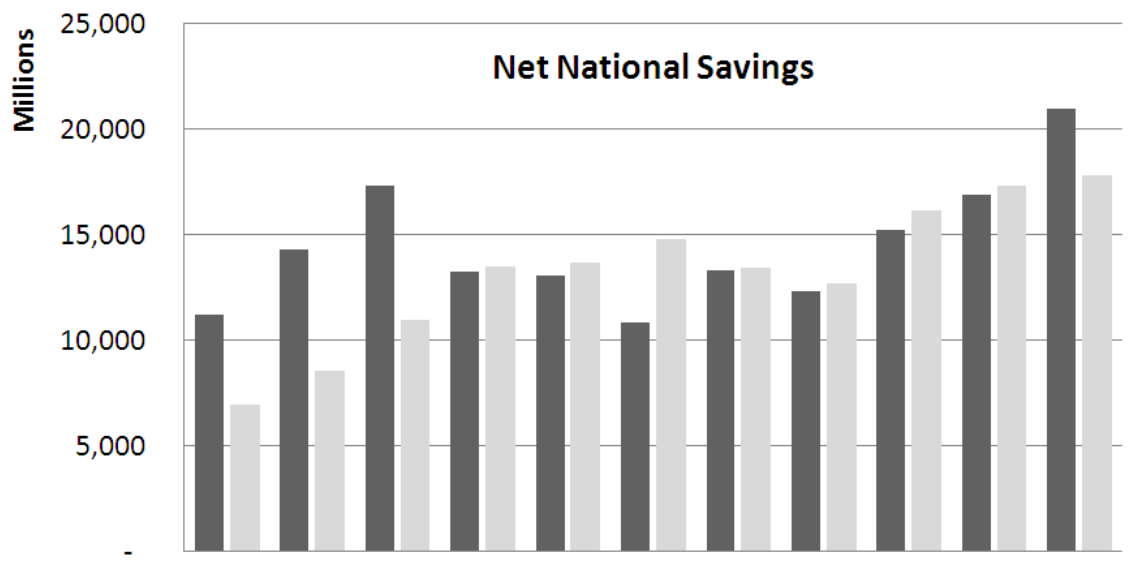

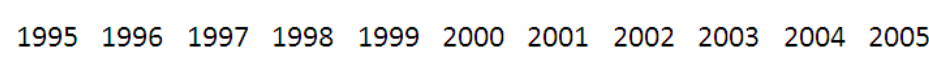

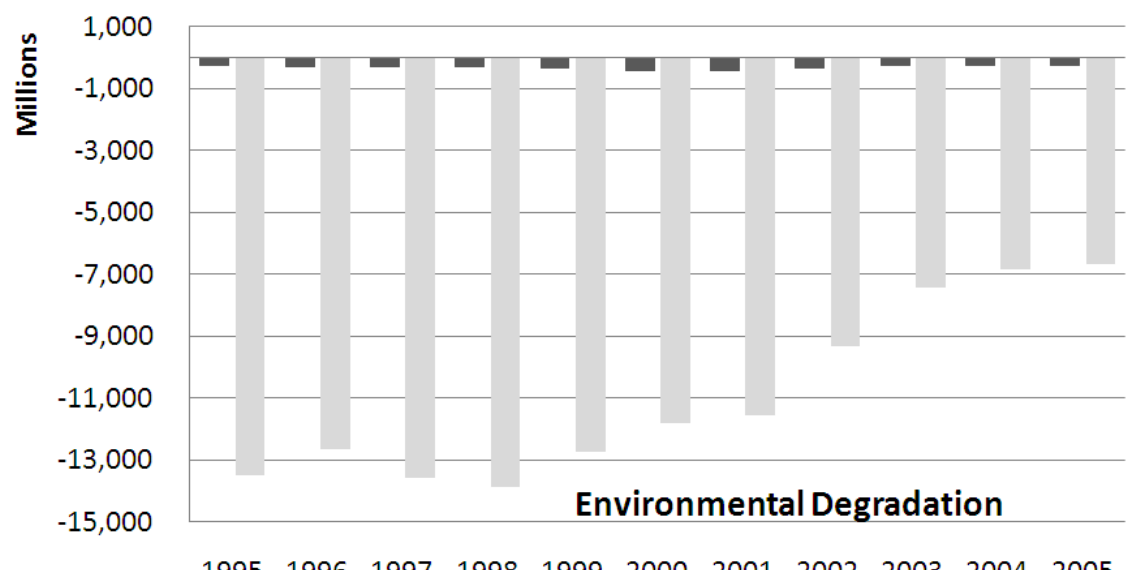

Estimates from WB
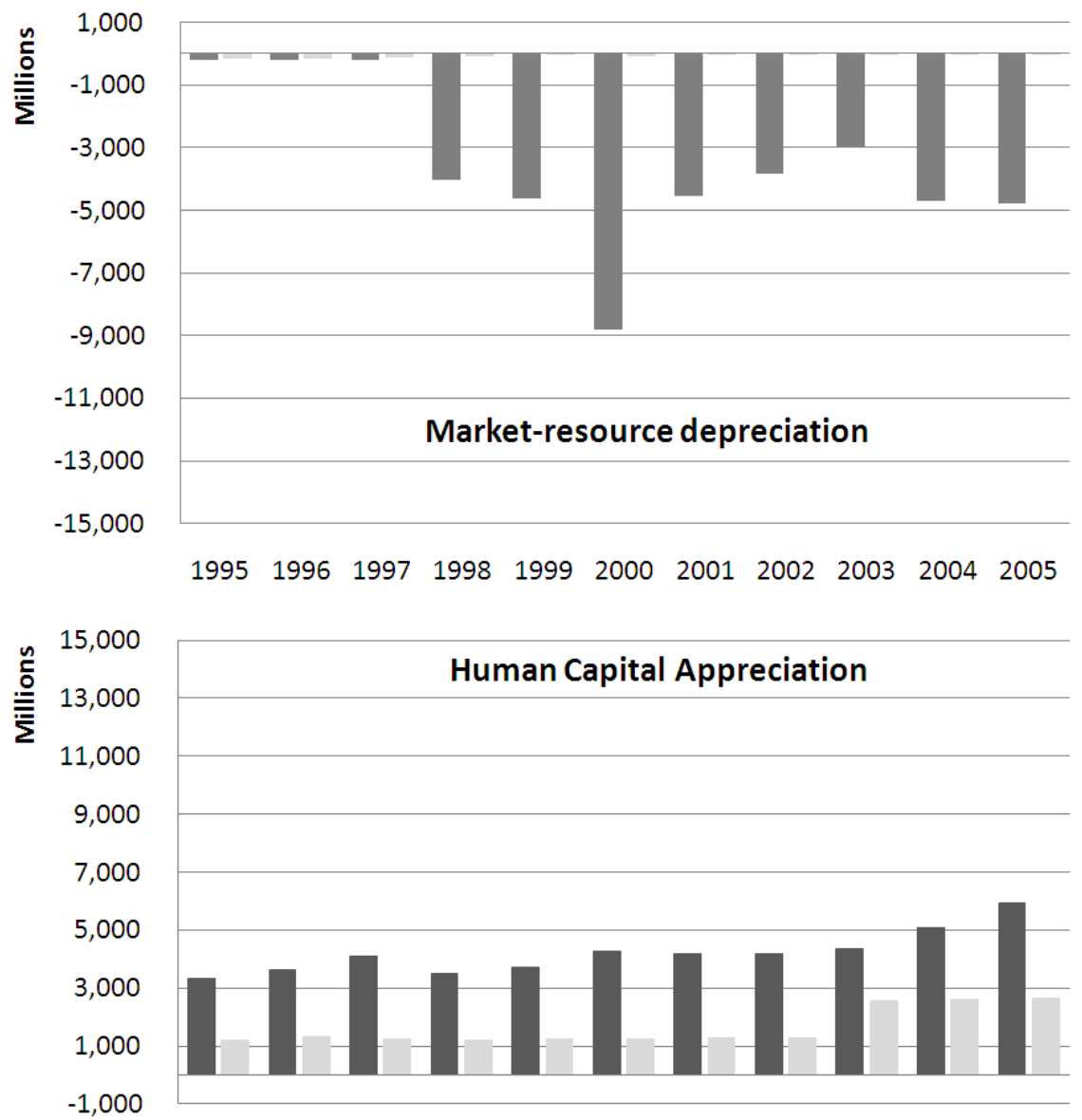

$\begin{array}{lllllllllll}1995 & 1996 & 1997 & 1998 & 1999 & 2000 & 2001 & 2002 & 2003 & 2004 & 2005\end{array}$

Our estimates

Figure 5 Differences in the components of World Bank (WB) and our genuine savings estimates 
Table 1 Robustness checks of our estimates of genuine savings (as percentage of GNI) and comparison with World Bank's (constant 2000 €)

\begin{tabular}{|c|c|c|c|c|c|c|c|}
\hline & (1) & (2) & (3) & (4) & (5) & (6) & (7) \\
\hline & $\begin{array}{l}\text { Benchmark } \\
\text { figures }\end{array}$ & $\begin{array}{l}\text { Human capital } \\
\text { accumulation = } \\
\text { Education } \\
\text { expenditure }\end{array}$ & $\begin{array}{l}\text { Marginal social } \\
\text { cost of carbon= } \\
\$ 20 / \mathrm{tC}\end{array}$ & $\begin{array}{c}\text { Marginal social } \\
\text { cost of carbon }= \\
\$ 67 / \mathrm{tC}\end{array}$ & $\begin{array}{l}\mathrm{SO}_{2} \text { emissions } \\
\text { allocated by } \\
\text { population }\end{array}$ & $\begin{array}{c}\mathrm{SO}_{2} \text { and } \mathrm{NO}_{2} \\
\text { damages from } \\
\text { Pezzey et al } \\
(2006)\end{array}$ & $\begin{array}{c}\text { World Bank } \\
\text { figures }\end{array}$ \\
\hline 1995 & $-5.05 \%$ & $-2.92 \%$ & $-5.59 \%$ & $-9.8 \%$ & $-3.3 \%$ & $0.9 \%$ & $19.3 \%$ \\
\hline 1996 & $-2.32 \%$ & $-0.31 \%$ & $-2.91 \%$ & $-7.3 \%$ & $-0.9 \%$ & $2.2 \%$ & $22.2 \%$ \\
\hline 1997 & $-0.91 \%$ & $1.37 \%$ & $-1.58 \%$ & $-6.4 \%$ & $0.6 \%$ & $4.0 \%$ & $23.9 \%$ \\
\hline 1998 & $1.16 \%$ & $3.55 \%$ & $0.43 \%$ & $-4.9 \%$ & $2.8 \%$ & $6.6 \%$ & $17.6 \%$ \\
\hline 1999 & $2.37 \%$ & $4.77 \%$ & $1.62 \%$ & $-3.9 \%$ & $3.7 \%$ & $6.8 \%$ & $16.0 \%$ \\
\hline 2000 & $4.26 \%$ & $6.82 \%$ & $3.37 \%$ & $-2.8 \%$ & $5.3 \%$ & $9.0 \%$ & $11.3 \%$ \\
\hline 2001 & $3.43 \%$ & $6.20 \%$ & $2.35 \%$ & $-4.8 \%$ & $4.3 \%$ & $8.1 \%$ & $14.2 \%$ \\
\hline 2002 & $4.45 \%$ & $7.60 \%$ & $3.25 \%$ & $-4.6 \%$ & $5.1 \%$ & $8.3 \%$ & $14.0 \%$ \\
\hline 2003 & $9.97 \%$ & $12.13 \%$ & $8.70 \%$ & $1.0 \%$ & $10.3 \%$ & $10.8 \%$ & $17.6 \%$ \\
\hline 2004 & $11.34 \%$ & $13.72 \%$ & $10.00 \%$ & $2.5 \%$ & $11.6 \%$ & $12.3 \%$ & $17.6 \%$ \\
\hline 2005 & $11.65 \%$ & $14.22 \%$ & $10.22 \%$ & $2.6 \%$ & $11.7 \%$ & $12.8 \%$ & $18.6 \%$ \\
\hline
\end{tabular}

Note: the values of the several genuine savings indicators computed under different assumptions are expressed as percentage of gross national income. 


\section{Appendix A}

The value of an asset is the discounted sum of resource rents associated with its use over its lifetime. For a depletable resource (or for a renewable resource under unsustainable management) this is given by:

$S_{t}=\sum_{n=0}^{T}\left(p_{t+n}-c_{t+n}\right) R_{t+n} /(1+r)^{n}$,

where $p$ and $c$ are the price and cost of a unit of extracted resource, $R$ is the amount extracted, $r$ is the discount rate and $T$ is the last year of extraction. In order to compute the adjustment to genuine savings in practice, we are interested in the change in value between the beginning and the end of an accounting period:

$$
S_{t+1}-S_{t}=r S_{t+1} /(1+r)-\left(p_{t}-c_{t}\right) R_{t},
$$

which, according to (A2) is equal to the foregone value of keeping the resource intact at time $t$ (first term in the RHS) minus the current economic rent.

There are many methodologies to estimate the depletion or accumulation of assets. These methods balance the needs for data (which are not easily available) with the need for deriving the correct adjustment to national savings. For example, the term $S_{t+1}$ in (A2) depends on the lifetime of the asset and on future prices and costs (this is more evident in equation (A1)). Therefore, information on deposit lifetime is crucial, and assumptions regarding discount rates, future prices and costs need to be made.

The simple present value method assumes constant unit rents and extraction rate (see Perman et al., 2003). The assumption of constant price runs counter the Hotelling rule of rising prices as depletion occurs. However, it fits well with the stylised facts in commodity markets; over the last decades the trend in real prices has been flat or slightly declining (Atkinson and Hamilton, 2007; Simpson et al., 2005).

In contrast, the net-price method, typically used in the early applied studies (see e.g., Repetto et al., 1989), and currently used by the World Bank, computes depletion by focussing solely on the second term of equation (A2) and ignoring the first term. An advantage of this method is its modest data requirement (it does not require interest rates, or lifetime of the deposit). The shortcoming is that it may result in large fluctuations in depreciation estimates (see e.g., Seroa da Motta and Ferraz do Amaral, 
2000). For this reason it is not recommended in the UN guidelines for environmental accounting (UN, 1993) and by other authors (see e.g., Atkinson and Hamilton, 2007).

In what follows, we will focus on both terms of the RHS of equation (A2) to derive asset depreciation. We therefore need to assume a constant unit rent and rate of extraction. Under these assumptions, we can rewrite equation (A1) as:

$$
S_{t}=\sum_{n=0}^{T}(p-c) R /(1+r)^{n}
$$

and equation (A2) as:

$$
S_{t+1}-S_{t}=D_{S t}=-(p-c) R /(1+r)^{T} .
$$




\section{Appendix B.}

Table B1. A summary of data sources used to construct the Irish Genuine Savings

\begin{tabular}{|c|c|c|c|c|}
\hline $\begin{array}{l}\text { Natural } \\
\text { resourc } \\
\text { es }\end{array}$ & Production/extraction & Prices & Costs & Lifetime \\
\hline Zinc & \multirow{3}{*}{$\begin{array}{l}\text { Exploration and Mining Division, } \\
\text { Department of Communications, } \\
\text { Energy and Natural Resources, } \\
\text { Ireland }\end{array}$} & \multirow{3}{*}{$\begin{array}{l}\text { Extern } \\
\text { al } \\
\text { Trade } \\
\text { data } \\
\text { from } \\
\text { Eurost } \\
\text { at }\end{array}$} & \multirow[b]{3}{*}{$\begin{array}{l}\text { Ben Dhonau, } \\
\text { Principal } \\
\text { Geologist, } \\
\text { Exploration } \\
\text { and Mining } \\
\text { Division, } \\
\text { Department } \\
\text { of } \\
\text { Communicati } \\
\text { ons, Energy } \\
\text { and Natural } \\
\text { Resources, } \\
\text { Ireland, } \\
\text { personal } \\
\text { communicatio } \\
\text { n May 2008) }\end{array}$} & \multirow[b]{3}{*}{$\begin{array}{l}\text { Wayne Cox, } \\
\text { Senior } \\
\text { Geologist, } \\
\text { Exploration } \\
\text { and Mining } \\
\text { Division, } \\
\text { Department } \\
\text { of } \\
\text { Communicati } \\
\text { ons, Energy } \\
\text { and Natural } \\
\text { Resources, } \\
\text { Ireland, } \\
\text { personal } \\
\text { communicatio } \\
\text { n (18 June } \\
\text { 2008) }\end{array}$} \\
\hline Lead & & & & \\
\hline Silver & & & & \\
\hline $\begin{array}{l}\text { Natural } \\
\text { Gas }\end{array}$ & $\begin{array}{l}\text { Michael Hanrahan, Petroleum affair } \\
\text { division, Department of } \\
\text { Communications, Energy and } \\
\text { Natural Resources, Ireland }\end{array}$ & \multicolumn{3}{|c|}{$\begin{array}{l}\text { World Bank } \\
\text { (go.worldbank.org/8CWDARYMB0) }\end{array}$} \\
\hline Peat & $\begin{array}{l}\text { Bord na Mona, Annual Reports, } \\
\text { various years }\end{array}$ & $\begin{array}{l}\text { Unit } \mathrm{r} \\
\text { operatil } \\
\text { tonne o } \\
* \% \text { of } \\
\text { from } \\
\text { activitic } \\
\text { Charles } \\
\text { Strateg } \\
\text { Manag } \\
\text { Mona, } \\
\text { commu } \\
\text { 2008) }\end{array}$ & $\begin{array}{l}\text { ent }=\text { Annual } \\
g \text { profit per } \\
\text { peat produced } \\
\text { annual revenue } \\
\text { milled peat } \\
\text { S Shier, } \\
\text { c Development } \\
\text { B, Bord na } \\
\text { personal } \\
\text { nication (July }\end{array}$ & $\begin{array}{l}\text { Bord na } \\
\text { Mona, } \\
\text { Annual } \\
\text { Reports, } \\
\text { various years }\end{array}$ \\
\hline Forests & \multicolumn{4}{|l|}{ Clinch and Murphy (2001) } \\
\hline $\begin{array}{l}\text { Air } \\
\text { polluti } \\
\text { on }\end{array}$ & Emissions & \multicolumn{3}{|c|}{ Marginal costs/damages } \\
\hline $\mathrm{CO} 2$ & $\begin{array}{l}\text { Irish emissions from Central } \\
\text { Statistics Office, Ireland. } \\
\text { Worldwide emissions from World } \\
\text { Development Indicators, World } \\
\text { Bank (available online at } \\
\text { http://databank.worldbank.org/ddp/ }\end{array}$ & \multicolumn{3}{|c|}{$\begin{array}{l}\text { Method 1. Social cost of carbon from } \\
\text { Tol (2005) and Tol (2008) } \\
\text { Method 2. } \\
\text { Damages to Ireland from worldwide } \\
\text { emissions (assumed to be equal to } \\
\text { European average) from Nordhaus and }\end{array}$} \\
\hline
\end{tabular}




\begin{tabular}{|c|c|c|}
\hline & $\underline{\text { home.do) }}$ & $\begin{array}{l}\text { Boyer (2000) } \\
\text { Global GDP from World Development } \\
\text { Indicators, World Bank, available } \\
\text { online } \\
\text { http://databank.worldbank.org/ddp/hom } \\
\underline{\text { e.do }} \\
\text { Social cost of carbon from Tol (2005) } \\
\text { and Tol (2008) }\end{array}$ \\
\hline PM10 & \multicolumn{2}{|l|}{$\begin{array}{l}\text { World Bank } \\
\text { (go.worldbank.org/8CWDARYMB0) }\end{array}$} \\
\hline $\mathrm{SO} 2$ & Lyons et al., (2008) & Holland and Watkiss (2002) \\
\hline NOx & Lyons et al., (2008) & Holland and Watkiss (2002) \\
\hline NO2 & Lyons et al., (2008) & Pezzey et al. (2006) \\
\hline \multirow[t]{2}{*}{$\begin{array}{l}\text { Human } \\
\text { capital }\end{array}$} & $\begin{array}{l}\text { Labor force y educational } \\
\text { attainment }\end{array}$ & Returns to education \\
\hline & $\begin{array}{l}\text { Census of population }(1992,1997, \\
2003,2007)\end{array}$ & $\begin{array}{l}\text { Barret el al (2002) and Irish } \\
\text { Department of Education and Science } \\
\text { (www.cso.ie/px/des/database/des/des.as } \\
\text { p) } \\
\text { Hours worked per week from Central } \\
\text { Statistics Office (see Footnote } 30)\end{array}$ \\
\hline
\end{tabular}




\section{Appendix C}

Table C1 Genuine Savings for the Republic of Ireland, 1995-2005 (Constant €2000)

\begin{tabular}{rrrr}
\hline Panel A & \multicolumn{3}{l}{} \\
\cline { 2 - 4 } & Genuine Savings $(\mathrm{r}=2 \%)$ & Genuine Savings $(\mathrm{r}=4 \%)$ & Genuine Savings $(\mathrm{r}=6 \%)$ \\
\cline { 2 - 4 } 1995 & $-5,511,161,052$ & $-5,482,017,884$ & $-5,458,666,106$ \\
1996 & $-2,982,595,537$ & $-2,952,840,020$ & $-2,929,090,166$ \\
1997 & $-1,540,872,885$ & $-1,512,089,721$ & $-1,489,690,333$ \\
1998 & $733,930,030$ & $753,797,247$ & $768,410,513$ \\
1999 & $2,154,223,007$ & $2,168,132,487$ & $2,177,776,669$ \\
2000 & $4,090,656,962$ & $4,123,696,251$ & $4,145,654,030$ \\
2001 & $3,087,395,921$ & $3,112,394,106$ & $3,126,412,825$ \\
2002 & $4,551,712,007$ & $4,568,160,114$ & $4,577,975,990$ \\
2003 & $11,223,042,859$ & $11,237,882,070$ & $11,245,739,317$ \\
2004 & $13,043,173,142$ & $13,061,502,557$ & $13,072,483,388$ \\
2005 & $13,742,255,136$ & $13,764,386,329$ & $13,776,079,839$ \\
\hline
\end{tabular}

\section{Panel B}

Genuine Savings (r=2\%) $\quad$ Genuine Savings (r=4\%) $\quad$ Genuine Savings (r=6\%)

$\begin{array}{lrrr}1995 & -4,917,242,386 & -4,888,099,219 & -4,864,747,440 \\ 1996 & -2,429,628,139 & -2,399,872,622 & -2,376,122,769 \\ 1997 & -1,065,236,184 & -1,036,453,020 & -1,014,053,632 \\ 1998 & 1,171,636,697 & 1,191,503,914 & 1,206,117,180 \\ 1999 & 2,600,501,379 & 2,614,410,859 & 2,624,055,042 \\ 2000 & 4,788,754,045 & 4,821,793,334 & 4,843,751,113 \\ 2001 & 3,698,562,521 & 3,723,560,706 & 3,737,579,424 \\ 2002 & 4,716,687,006 & 4,733,135,114 & 4,742,950,989 \\ 2003 & 10,892,844,831 & 10,907,684,043 & 10,915,541,289 \\ 2004 & 12,547,437,799 & 12,565,767,213 & 12,576,748,045 \\ 2005 & 13,175,550,564 & 13,197,681,757 & 13,209,375,267\end{array}$

Note: Panel $\mathrm{A}$ and $\mathrm{B}$ differ in the way $\mathrm{CO}_{2}$ adjustments were computed. In Panel A, Irish $\mathrm{CO}_{2}$ emissions are valued at the global social cost of carbon and subtracted from net national savings (i.e. property rights to the atmosphere lie with the pollutee).In Panel $\mathrm{B}, \mathrm{CO}_{2}$ damages to Ireland from global emissions are considered (i.e. property rights to the atmosphere lie with the polluter). For details, see Sections 3.3 and 2.2.3. 


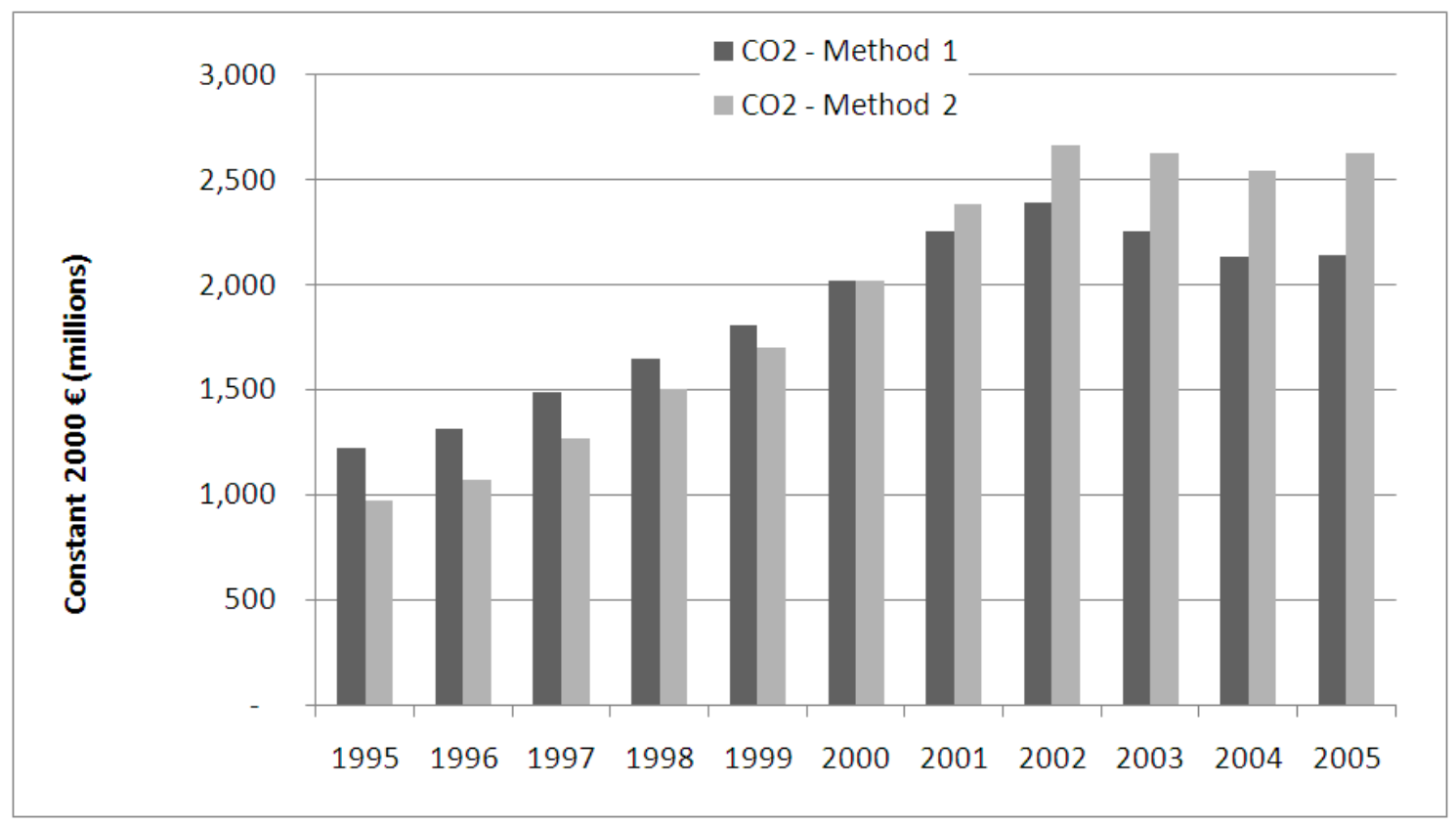

Figure C1. Comparison between $\mathrm{CO}_{2}$ damages under different property rights

Note: Method 1 charges global damages to emitting countries on the assumption that the property right to a clean environment lies with the pollutee. Method 2 estimates damages to Ireland arising from global emissions (i.e. property rights to use the atmosphere as a sink lie with the polluter). The second method produces lower negative figures at the beginning of the period (i.e., when GS are negative). For conservative reasons we use Method 2 in all the figures reported in the paper. 